\title{
The Paleohistory of Circumpolar Arctic Colonization
}

\author{
JANUSZ KOZLOWSKI* and H.-G. BANDI ${ }^{\dagger}$
}

\section{INTRODUCTION}

The occupation of the Arctic is indisputably linked to the progress of adaptation of paleolithic peoples to the conditions of the periglacial zone during the last glaciation. It was this phenomenon alone which allowed human groups to acquire the means with which to confront the ecological and climatic conditions of the Arctic, although the characteristic conditions of this zone are not identical to those of the Pleistocene periglacial zone which extended to much more southerly latitudes. Unfortunately, it is difficult to follow the movements of human groups towards the north because of the several advances by northern glaciers which have covered human traces in the northern regions of Eurasia and America with a thick layer of moraine and fluvioglacial deposits. This movement has to be reconstructed from isolated traces, particularly in those rare sectors of the far Eurasian north which were not covered by the ice sheet during the Würm glaciation.

These observations enable us to reconstruct the prehistoric cultures which spread into northern Eurasia and to relate them to the climatic pattern of the Upper Pleistocene. These cultures developed under the influence of the periglacial environment, sometimes in regions situated much further south. Stone tools, settlement structures, ways of life, and arts and crafts which developed at this time belonged to cultural traditions that per- sisted for long periods and occupied zones which were sometimes very extensive.

The first adaptations to arctic environments date from the end of the Lower Paleolithic, during the penultimate glaciation (Riss/Sáale + Warte/Dnieprovskoye + Moskovskoye), when the periglacial zone extended far to the south, covering the contemporary temperate zone. Unfortunately, we have no idea of the northern limit of human occupation at this period. The map of Acheulian settlements shows that in Europe and Asia this limit was not very far to the north, rarely approaching the Riss periglacial zone (Collins, 1969). It is more often the Clactonian and Pre-Charentian sites which spread into the more northerly periglacial zone, as their flake-tool industry was better adapted to the periglacial environment (Figs. 1, 2).

Our study of the settlement of the Arctic by prehistoric human groups is thus limited to the period between the last interglacial phase and the beginning of the Holocene. From the point of view of the paleogeographical conditions pertaining to the northerly advance of human groups, three stages of this period which fostered this phenomenon may be distinguished: 1) The last interglacial period (Riss/Würm/Eemien/Mikulino/ Kazantsevo); 2) The Würm Interpleniglacial period (Briansk/ Kargino); and 3) The Tardiglacial phase and the Holocene.

One of the two Würm pleniglacial phases, that of Plenigla-
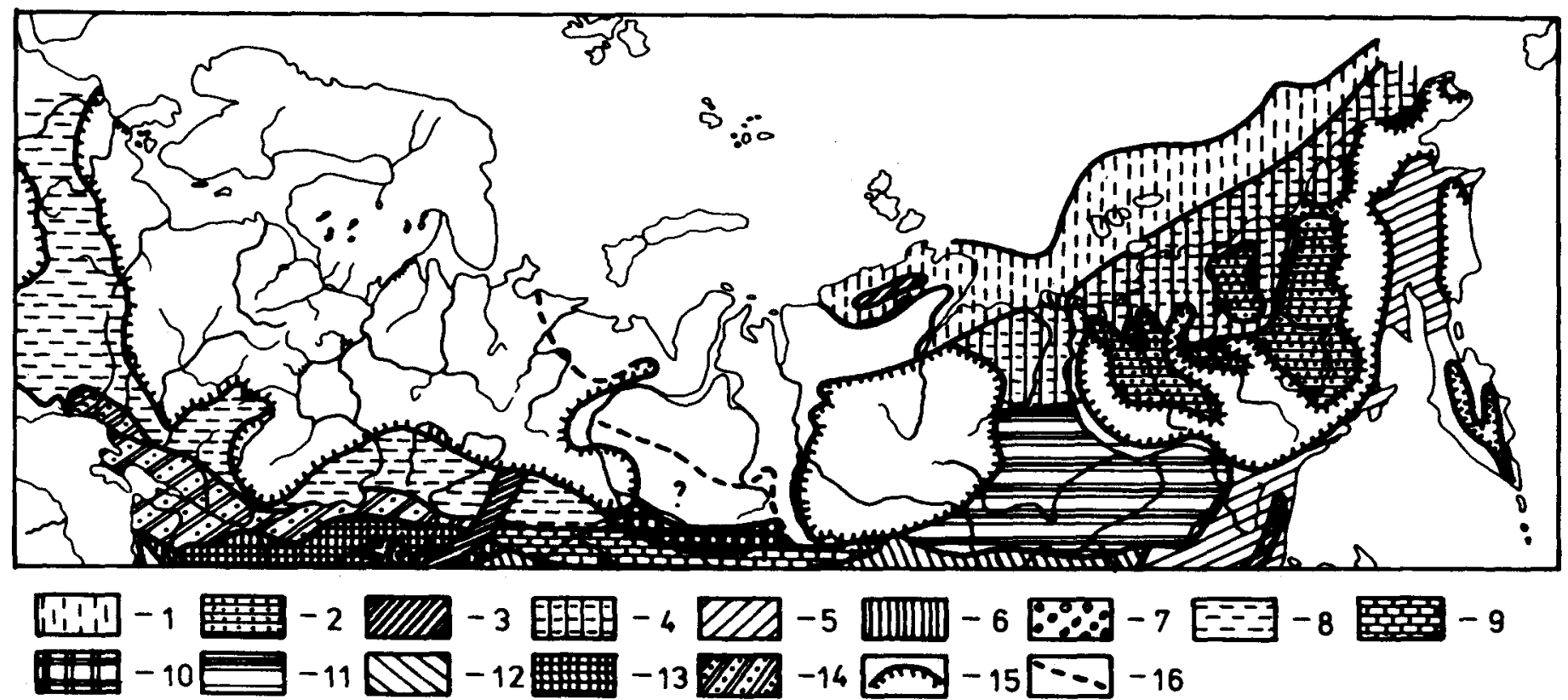

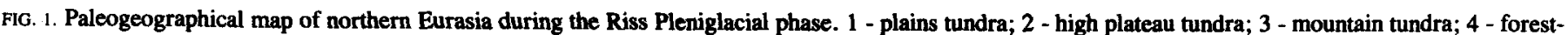

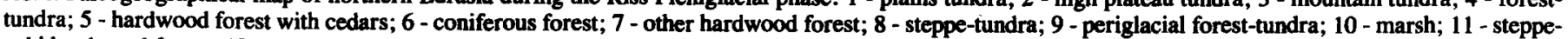

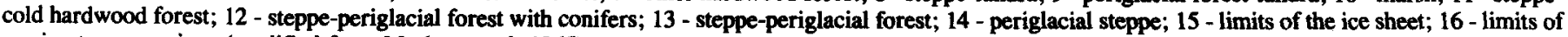
marine transgressions (modified from Markov et al. , 1965). 


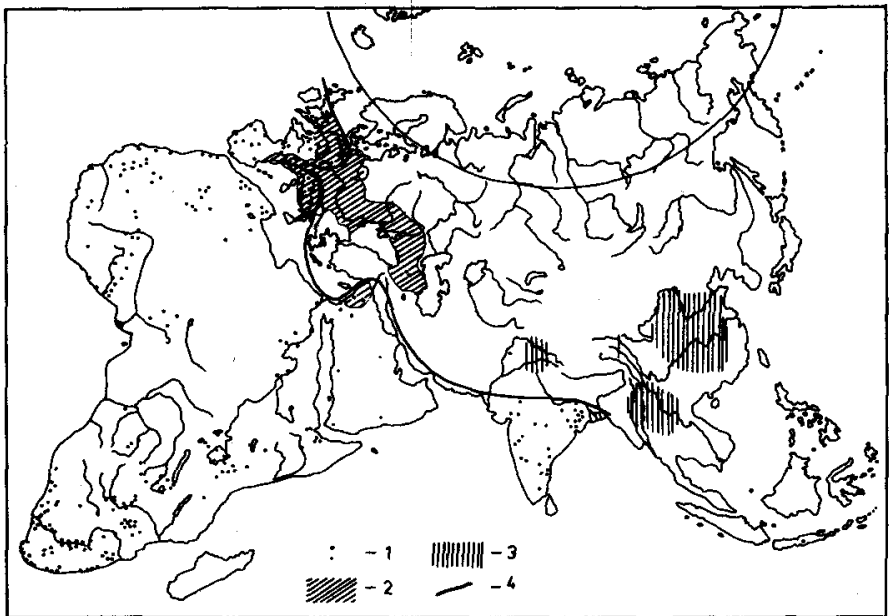

FIG. 2. Distribution of Lower Paleolithic industries. 1 - Acheulian; 2 - ProtoCharentian and Clactonian; 3 - chopper and pebble tool industries; 4 - arctic zone (modified from Collins, 1969).

cial " A" corresponds to Würm I and II as well as to the Leningrad stage, to the Zyrianka glaciation in Siberia, and to the Ancient Wisconsin in America. Pleniglacial " $B$ " corresponds to Würm IV as well as to the Valdai stage, to the Sartan glaciation in Siberia, and to the Recent Wisconsin in America. Both phases considerably limited human occupation and rendered inaccessible most of the far Eurasian north.

Europe, Asia, and America must be considered separately in examining the process of settlement of the Arctic. Each continent is characterized by specific paleogeographical conditions and different cultural traditions which contributed to the colonization of its particular arctic zone. In Europe, the region between the Fenno-Scandinavian ice sheet and the Urals (the northern part of the Russian Plain) was easily accessible during the last glaciation. On the other hand, the FennoScandinavian platform was open to colonization only at the end of the last glaciation and during the Holocene. In Asia, the Siberian far north was practically inaccessible because of a major transgression of the Arctic Ocean into the western zone, and because of the glaciers which spread over the plateaus of central Siberia. Only northeastern Siberia and the Pacific coastal area, widened by the retreating sea, were accessible during the Würm. This same retreat of the Pacific produced a land bridge between Asia and America known as Beringia, which made possible the first incursions into the ice-free northwest of the American continent. In America, the ice sheet formed two zones, the Laurentian in the east and the Cordilleran in the west. The corridor between them, during the periods when it was open, facilitated communication with the other parts of the New World.

The evolution of paleogeographical conditions meant that the colonization of the Arctic was not a continuous process but occurred in several waves, of which only the last, which dates from the Tardiglacial and the Holocene phases, contributed to the evolution of certain contemporary arctic peoples.

\section{THE PALEOHISTORY OF THE EUROPEAN FAR NORTH •}

Conditions favourable to human-occupation existed in the Eurasian far north during the Riss-Würm interglacial phase, in spite of a major advance of the Arctic Ocean which submerged western Siberia and much of the northern Russian Plain. The same advance made a temporary island of Scandinavia. Thanks to a considerable climatic warming, coniferous forests spread through the area as far as the shores of the Arctic Ocean
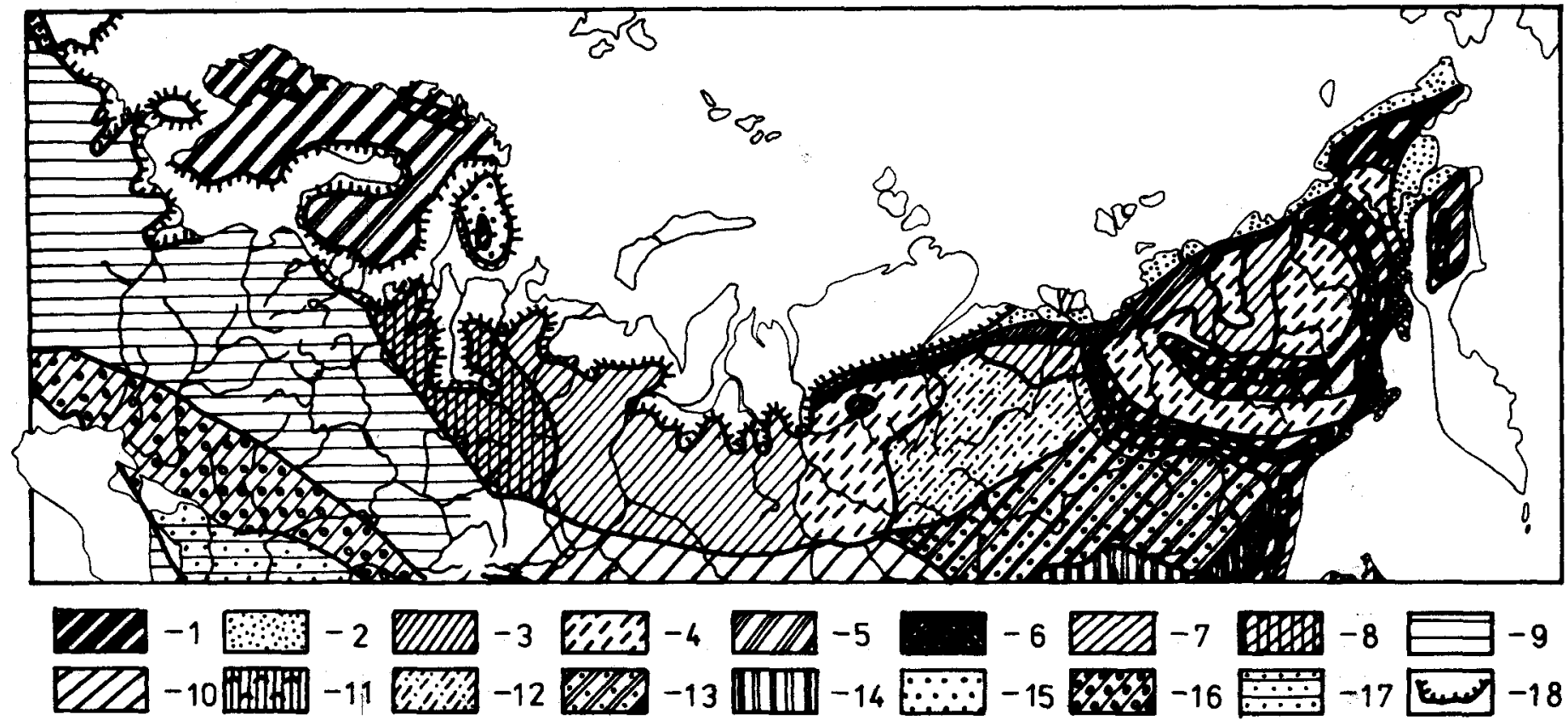

FIG. 3. Paleogeographical map of northern Eurasia during the last interglacial phase (Eemien, Riss-Würm). 1 - mountain tundra; 2 - plains tundra; 3 - foresttundra; 4 - hardwood and mixed plains/plateau forest; 5 - hardwood and mixed mountain forest; 6 - coniferous forest; 7 - taiga; 8 - mixed forest; 9 - hardwood forest; 10 - pine and cedar forest; 11 - birch and coniferous forest; 12 - sparse forest; 13 - forest with clearings; 14 - savanna; 15 - mountain steppe; 16 - steppeforest; 17 - steppe; 18 - limit of marine transgressions (modified from Markov et al., 1965). 
(Fig. 3), even giving them access to human groups not adapted to periglacial conditions. Unfortunately, only one archaeological site is currently known in the ancient northern European littoral, dating from the end of the last interglacial phase. This is the site of Krutaya Gora on the River Petchora, at about $65^{\circ} \mathrm{N}$ latitute, $175 \mathrm{~km}$ south of the Arctic Circle. The lowest level of this site is at the base of a series of gravel layers, probably of marine-lacustrine origin, and forming a terrace of $40 \mathrm{~m}$. At this level, lithic tools are typically Mousterian (Fig. 4 ), but this assemblage is unfortunately too poor to be con-
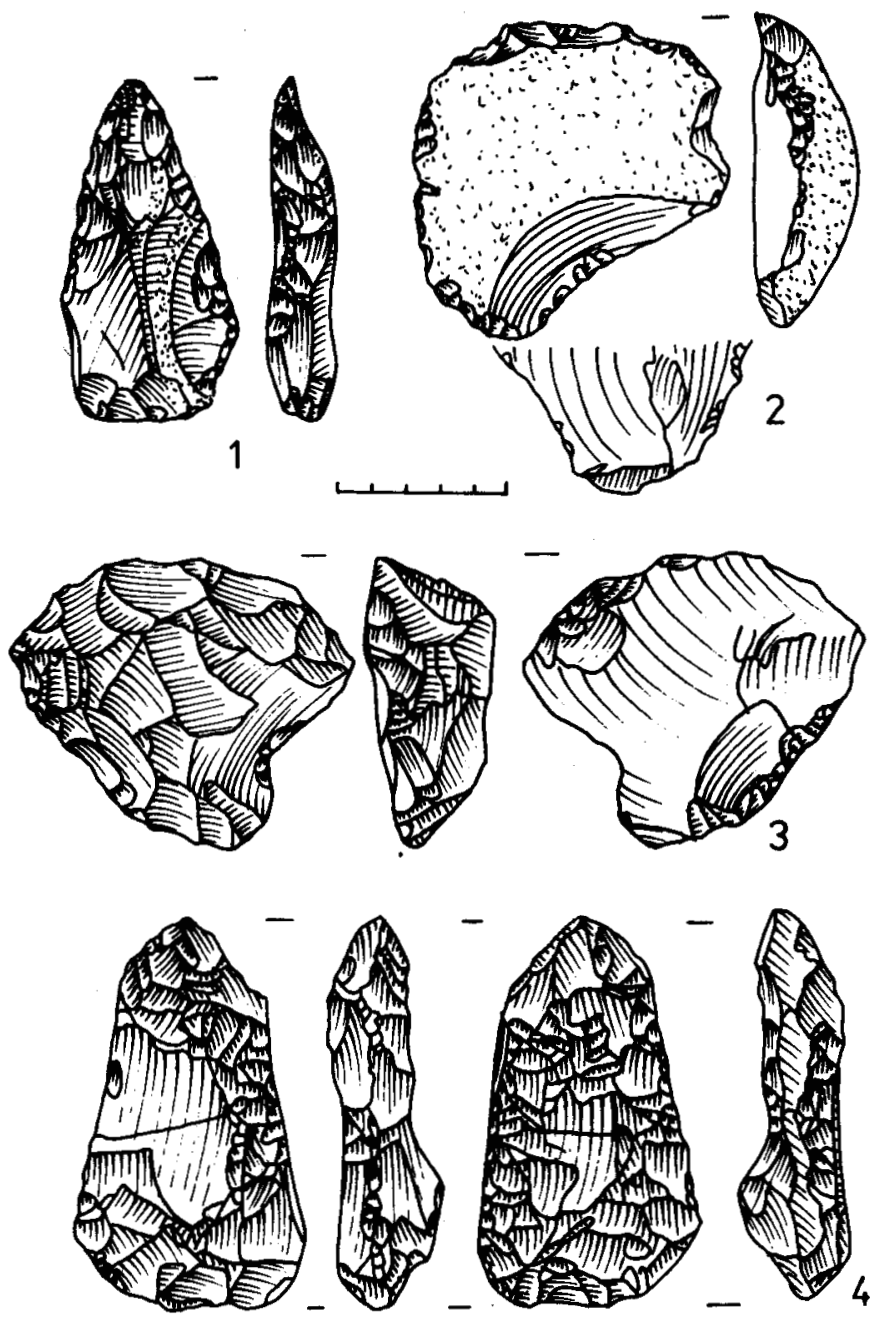

FIG. 4. Krutaya Gora $\left(65^{\circ} \mathrm{N}\right)$, lower level. Middle Paleolithic industry: 1 - Mousterian point; 2,3 - sidescrapers; 4 - biface (Kanivets, 1976). nected to the well-established typology of the Mousterian period known in eastern Europe. It is probably an industry rich in scrapers and containing bifacial forms known in the Russian Plain as Starosiele or Sukhaya Metchetka types (Kanivets, 1976). This site remains, for the moment, isolated in the far north of Europe. At the beginning of the Würm there was, within the framework of the Mousterian complex, an adaptation to periglacial conditions. This adaptation appears mainly in Quina tool industries, which penetrated into the periglacial zone as early as the end of the Riss period. During the Early Würm phase this ecological orientation became much clearer, as shown by a comparison with other Mousterian types (Table 1; cf. Rolland, 1981).

The same phenomenon applies to cultures in central-eastern Europe (the facies of Ciemna in Poland, Sukhaya Metchetka and Starosiele in the Russian Plain) which are rich in scrapers and bifacial tools. Certain industries of this type penetrated into the periglacial zone of the early Würm (Fig. 5). Sites of such lithic industries are therefore to be found in the Polish Plain (Kozlowski and Kozlowski, 1977:70), in the central zone of the Russian Plain (Novo Bikhov, Kleevitchi, Khotylevo, and Negotino, all in the Dnieper and Desna basins; Zaverniayev, 1978), in the Kama basin (Gremiatchevo, at nearly $60^{\circ} \mathrm{N}$; Bader, 1971), and in the Urals (Pechtcherniy Log on the River Tchusovaya; Bader, 1955). The fauna of certain of these sites is characteristic of cold, dry climates (Madeyska, 1979); other sites show remnants of fauna more typical of steppes, and sometimes quite wooded environments (Gritchuk, 1969).

The appearance of leaf-shaped bifacial points is a characteristic phenomenon of the end of the Middle Paleolithic throughout the northern European zone. These points are found both in the context of Quina typology and in east European bifacial tool industries. Thus there is a spread of leaf point artifacts which characterize a large part of the European Plain at the beginning of the Upper Paleolithic. In this period, coincident with the Würm interpleniglacial phase, the Plain became accessible to human groups adapted to arctic conditions. During the first half of the Interpleniglacial phase (40 000-30 000 years BP), these lithic industries spread from England and Belgium (Kent Cavern and Goyet Cave complexes; Campbell, 1977, 1980; Otte, 1974) across Germany (the Ranis-Mauern culture; Hülle, 1978; Feustel, 1961) as far as Poland (Jerzmanowice complex; Chmielewski, 1961). We have no idea of how far north these cultures spread because of the moraine and fluvioglacial deposits of the later Würm

TABLE 1. Percentage frequency of cultural occurrence in various climate types associated with Early Würm archaeological layers and Mousterian industries ${ }^{1}$

\begin{tabular}{|c|c|c|c|c|c|c|c|}
\hline Facies & $\begin{array}{c}\text { Temperate, } \\
\text { very wet }\end{array}$ & $\begin{array}{c}\text { Temperate, } \\
\text { wet }\end{array}$ & $\begin{array}{c}\text { Average, } \\
\text { wet }\end{array}$ & $\begin{array}{c}\text { Cold, } \\
\text { wet }\end{array}$ & $\begin{array}{c}\text { Cold, } \\
\text { dry }\end{array}$ & $\begin{array}{l}\text { Very cold, } \\
\text { very dry }\end{array}$ & $\mathbf{N}$ \\
\hline Mousterian (Denticulated) & 8.7 & 36.9 & 28.3 & 8.7 & 10.9 & 6.5 & 46 \\
\hline Mousterian (Typical) & - & 14.3 & 29.9 & 22.1 & 26.0 & 7.8 & 77 \\
\hline Ferrassie & - & 4.0 & 8.0 & 48.0 & 40.0 & - & 25 \\
\hline Quina & - & 4.4 & 13.3 & 22.2 & 42.2 & 17.7 & 45 \\
\hline Total & 2.1 & 16.1 & 22.8 & 22.3 & 28.0 & 8.8 & 193 \\
\hline
\end{tabular}

'From N. Rolland (1981). 


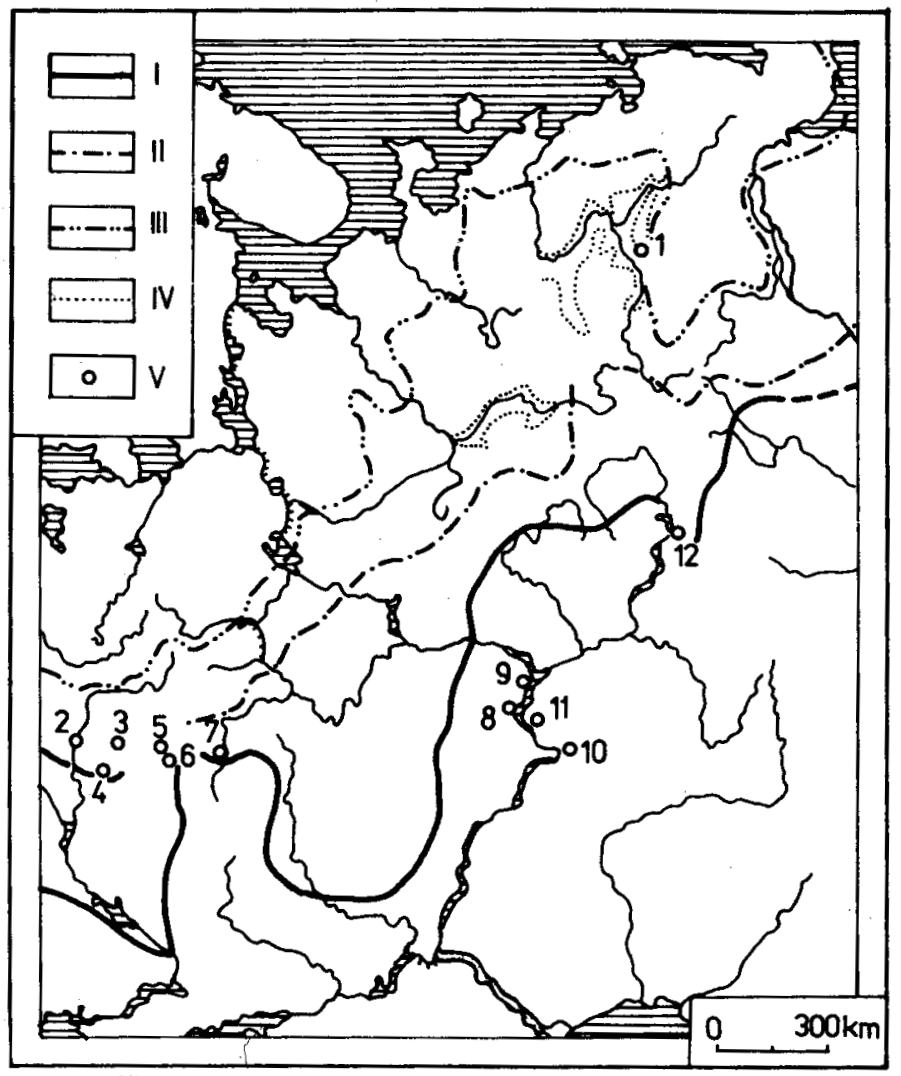

FIG. S. Middle Paleolithic in eastern Europe. I - limit of Riss I glaciation; II - limit of Riss II glaciation; III - limit of Würm I (Ancient Würm) glaciation; IV - advance of Arctic Ocean; V - Middle Paleolithic sites. Northern sites of eastern Europe: 1 - Krutaya Gora; 2 - Novo Bikhovo; 3 - Kleevitchi; 4 - Svetilovitichi; 5 - Khotylevo; 6 - Negotino; 7 - Khotojkov; 8 - Undory; 9 - Krasnaya Glinka; 10 - Barabashni Ovrag; 11 - Tunguz; 12 - Pechtchernyi Log; 13 - Gremiatchevo.

period which cover all of this region. However, we can follow the northerly movements of leaf point industries across the Russian Plain in the second half of the Interpleniglacial phase.

In this region, the Kostienki-Sungir complex represents a typical adaptation to a periglacial environment. By about $25000 \mathrm{BP}$, it occupied the most northerly location among

TABLE 2. Faunal remains on sites of the Kostienki-Sungir culture in the north of the Russian Plain

\begin{tabular}{lcc}
\hline Species & Sungir & Byzovayab \\
\hline Mammoth & numerous & $2051^{\mathrm{c} / 21^{\mathrm{d}}}$ \\
numerous & $1 \mathrm{c} / 1^{\mathrm{d}}$ \\
Horse & $\begin{array}{c}\mathrm{d} \\
\text { Rery abundant }\end{array}$ & - \\
Saiga antelope & 1 & - \\
Bison & 3 & - \\
Lion & 1 & - \\
Brown bear & 2 & - \\
Wolverine & 10 & $2 \mathrm{3}$ \\
Hare & 17 & - \\
Wolf & 16 & $1 \mathrm{c} / 1^{\mathrm{d}}$ \\
Arctic fox & numerous & - \\
Rhinoceros & - & - \\
Lemming & 3 & 1 \\
Black grouse & 1 & \\
\hline \hline
\end{tabular}

aFrom Gromov (in Soukatchev et al., 1966)

bFrom Kanivets (1976).

cNumber of bones.

dNumber of individuals. lithic industries of the Upper Paleolithic, at the well-known site of Sungir, near Vladimir $\left(56^{\circ} \mathrm{N}, 150 \mathrm{~km}\right.$ from the limit of the ice sheet of the second Würm Pleniglacial). The faunal remains at this site show that reindeer, mammoth, and horses were the principal animals hunted (Table 2). Such welldeveloped periglacial phenomena indicate the presence of permafrost, just as the presence of the lemming and arctic fox point to a rigorous climate, although saiga antelope, brown bear, and especially capercaillie were also present (Soukatchev et al., 1966). Adaptation to periglacial conditions by the inhabitants of Sungir is confirmed by the presence of settlement structures of mammoth bones. The structures were mostly rectangular, ranging in size from $9 \times 6 \mathrm{~m}$ to $15 \times 7 \mathrm{~m}$, with interior hearths. Periglacial conditions (solifluction and creep) have damaged these structures and it is not possible to reconstruct them in detail (Bader, 1978). Another aspect of adaptation is clothing, which it has been possible to reconstruct at burial sites containing skeletons covered with several thousand beads (Fig. 6). The distribution of the beads suggests that men and women wore a type of parka, long trousers, probably with feet like tights, and perhaps fur boots. This clothing is undoubtedly a prototype of the clothing of contemporary arctic peoples. Stone artifacts consists of triangular leaf points with concave bases (Fig. 7), scrapers,

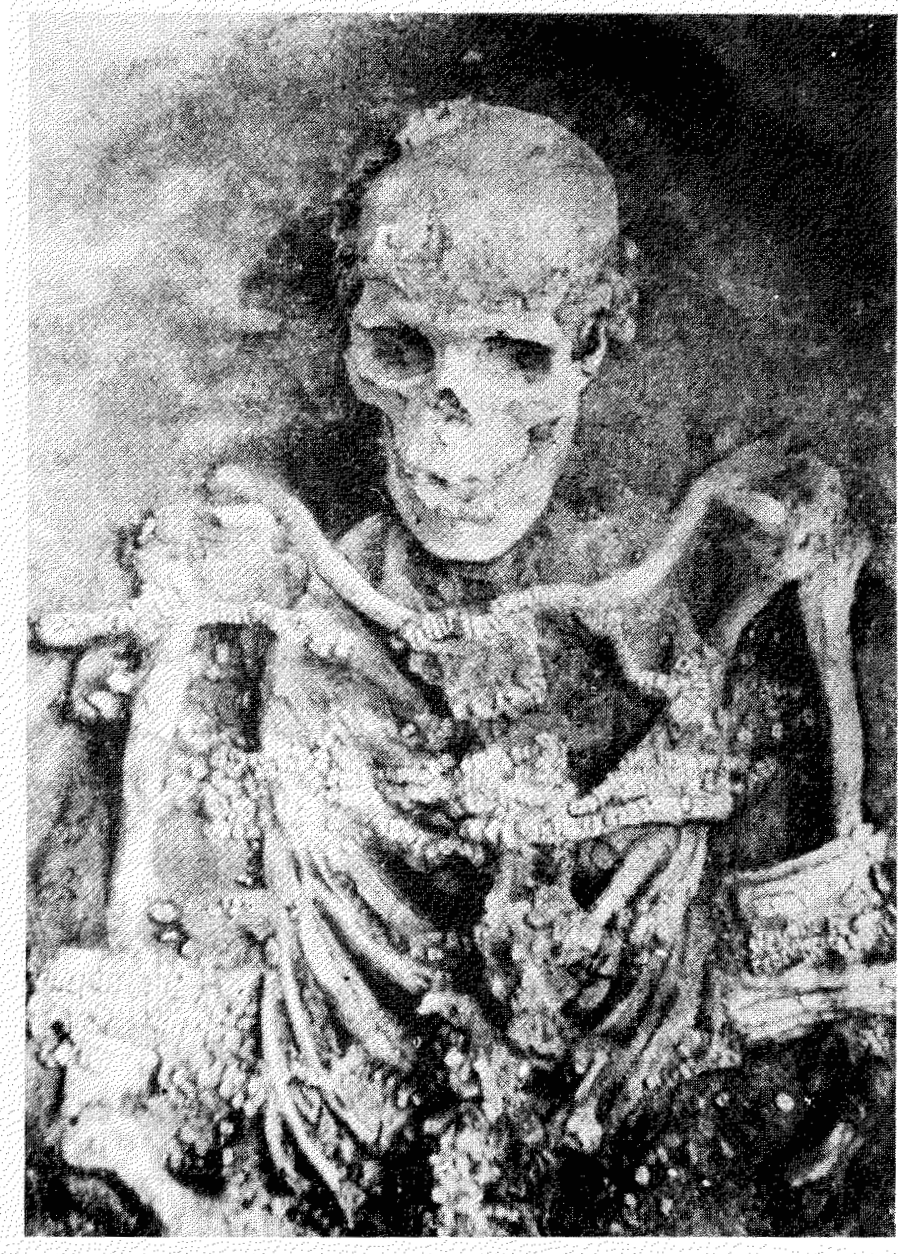

FIG 6 Sungir near Vladimir $\left(56^{\circ} \mathrm{N}\right)$. Upper Paleolithic burial site (Bader, 1978). 


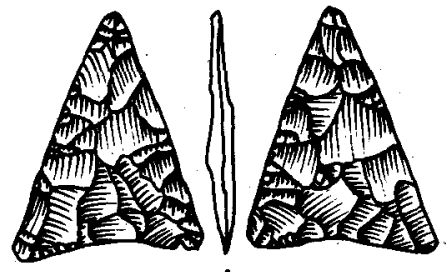

1

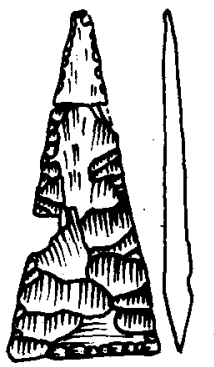

3

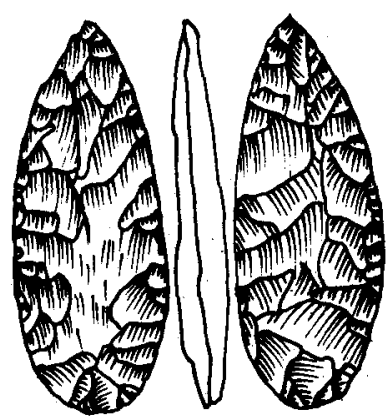

4

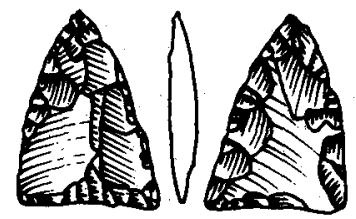

2

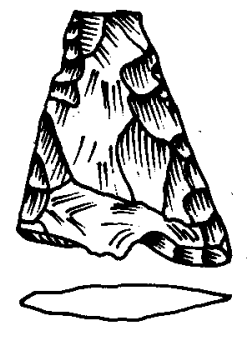

5
FIG. 7. Sungir near Vladimir: Bifacial leaf points (Bader, 1978).

splintered fragments, retouched blades, retouched perforators, and flakes. The bone and ivory artifacts are mainly long spears of oval section, wedge-shaped tools, and awls.

The Kostienki-Sungir culture advanced further north (Fig. 8) as far as the Petchora basin, where the Byzovaya site at $65^{\circ} \mathrm{N}$ has revealed an industry of leaf points, endscrapers (Fig. 9), sidescrapers, retouched flakes, and blades, among other artifacts (Kanivets, 1976). Radiocarbon dating of this site (18 $320 \pm 280 \mathrm{BP}$ ), contemporary with the phase of maximum

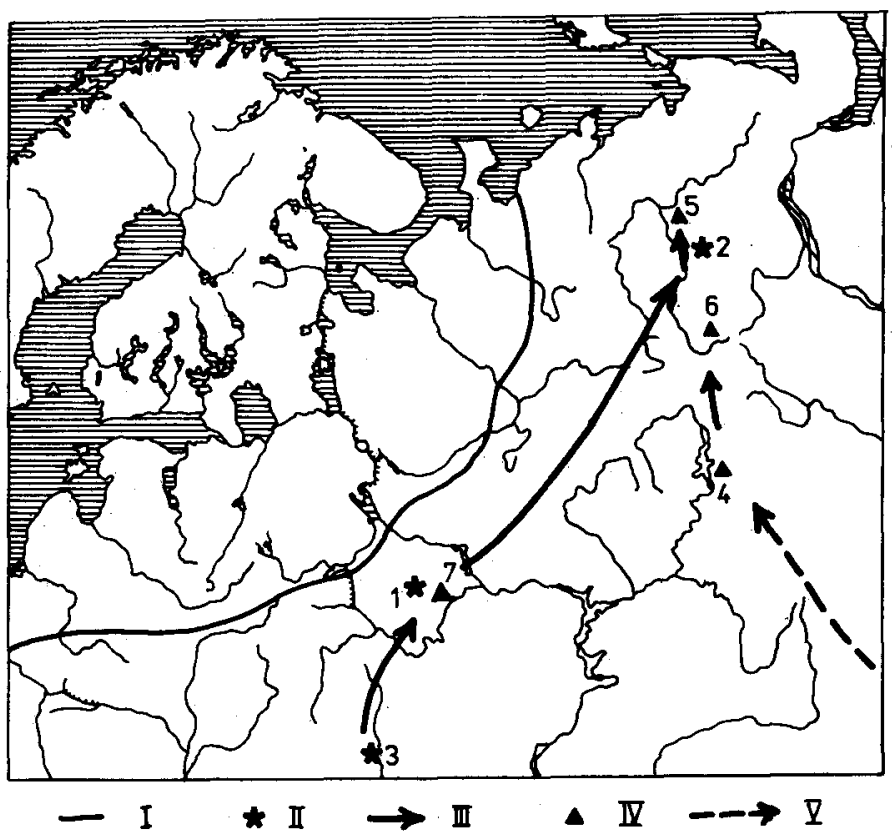

FIG. 8. The Upper Paleolithic in northeastern Europe. I - limit of ice sheet during Würm Pleniglacial phase; II - sites of Kostienki-Sungir culture; III - northern expansion of Kostienki-Sungir culture; IV - sites of Siberian tradition of final Upper Paleolithic; V - Tardiglacial northern expansion of Siberian tradition. Northern sites of the Upper Paleolithic: 1 - Sungir; 2 - Byzovaya; 3 - Kostienki; 4 - Talitskiy; 5 - Krutaya Gora (upper level); 6 - Medveja cave; 7 - Karatcharovo.

extent of the Würm glaciers, appears to be too recent, although the presence at this site of a backed point shows that it must be rather more recent than that of Sungir. The fauna of Byzovaya is characterized by a clear predominance of mammoth, much more numerous than reindeer, horse, or rhinoceros (Table 2). From the structure of the floor of the habitat, it is possible to envisage the existence of huts constructed with mammoth bones and tusks.

After the Interpleniglacial phase, the next stage in the conquest of Northern Europe coincided with the Tardiglacial phase. During the Interpleniglacial, leaf point cultures were typical of the peopling of the Great Plain of Europe; for the Tardiglacial, on the other hand, the tanged point cultures were distinctive. These cultures appear to be based either on the Magdalenian, during the Alleröd (for example, the Brommian or Bromme-Lyngby culture in northern Germany, Denmark, and southern Sweden; Bronsted, 1957; Taute, 1968), or on Kostienki-derived industries in the Plains of Russia and Poland during the Dryas III (the Swidérian; Schild, 1975, 1978; the Desna culture; Kozlowski, 1975:119). All these cultures were closely associated with reindeer hunting; their stone tools comprised principally tanged points, scrapers, and burins, sometimes with backed blades. Harpoons of the Havela and Torring types, Pantekinnen spears, and reindeer-antler axes of Lyngby (Lyngbybeile) undoubtedly played an important role as well.
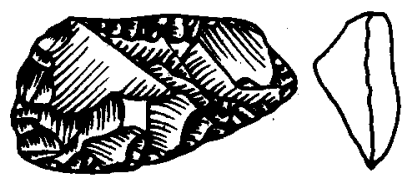

1
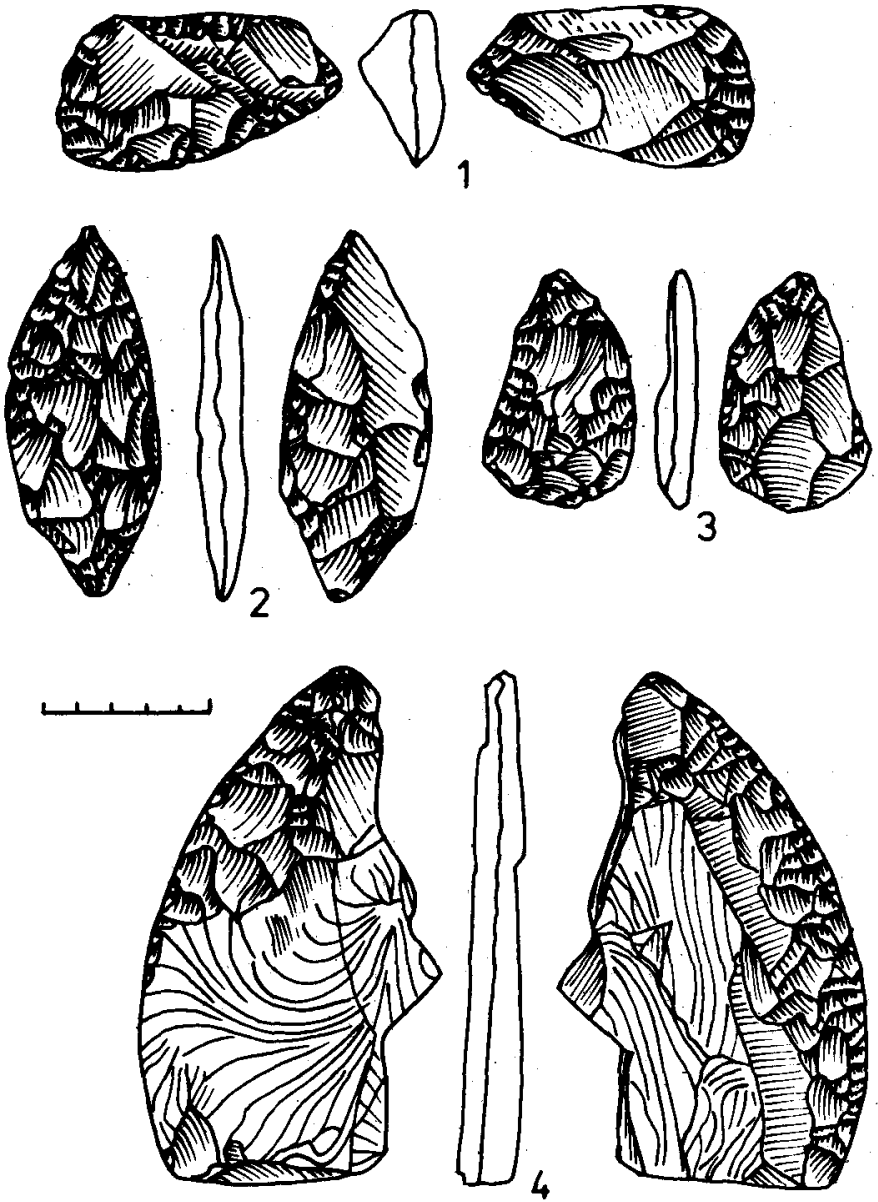

FIG. 9. Byzovaya $\left(65^{\circ} \mathrm{N}\right)$. Upper Paleolithic industry: 1 - sidescraper; 2,3 - leaf points; 4 - large arched sidescraper with bifacial retouch (Kanivets, 1976). 
All of these cultures, which represent an adaptation to periglacial conditions, followed the northward movement of the periglacial environment during the retreat of the ice. The migration towards the Baltic region and northern Scandinavia is confirmed by the appearance of new cultural entities in northern Europe, notably the Fosna culture in western Scandinavia (from the beginning of the eighth millenium B.C.; Clark, 1936), the Komsa culture of northern Scandinavia (from the beginning of the sixth millenium B.C.; Boe and Nummedal, 1936), and the Suomusjärvi culture in Finland (from the end of the eighth millenium B.C.; Luho, 1967).

These cultures all developed from Tardiglacial adaptations, particularly the tanged point industry. They continued traditional economies based on reindeer hunting, as periglacial conditions still existed at the beginning of the Holocene (in the far north - the Komsa culture - such conditions persisted until the Atlantic period). The origin of the cultures named refers to tanged point composite tools:

- that of the Fosna culture to the Brommian and the Ahrensburgian (same type of tanged points, to which were added geometric microliths used as inserts, although other elements such as tranchets and shouldered points are more suggestive of the Desna culture);
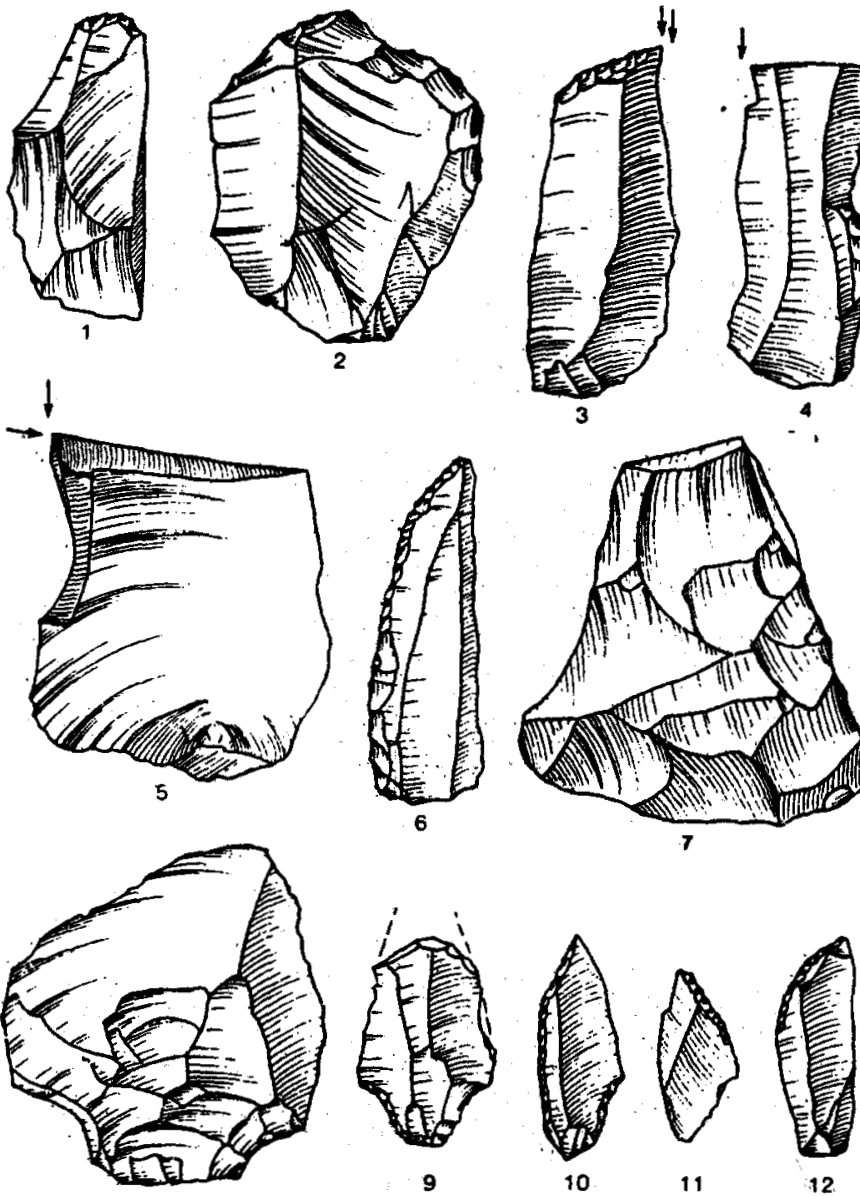

FIG. 10. Seilmerket. II $\left(68^{\circ} \mathrm{N}\right)$. Stone tool industry of the Komsa culture: 1,2 - endscrapers; 3-5 - burins; 6 - backed point; 7,8,9 - tanged implements; 10 - shouldered point; 11,12 - retouched truncations.
- that of the Suomusjärvi culture to the Desna culture (tanged points and shouldered points, accompanied by local artifacts represented by polished schist tools; e.g. .axes and daggers); and

- that of the Komsa culture to the Fosna and Suomusjärvi (tanged points, microliths, backed points, and polished stone axes; Fig. 10).

A different situation characterizes the northern part of the Russian Plain. During the Tardiglacial these regions were not subject to the influence of the final European Paleolithic but remained under the influence of Siberian cultures. The Talitski (or Ostrovskaya) site on the river Tchusovaya $\left(58^{\circ} \mathrm{N}\right)$ (Talitskii, 1940; Bader, 1960) shows a typological and technological structure close to the Siberian Upper Paleolithic: a laminar index of $<17$; the presence of side scrapers, thick end scrapers, short scrapers, and finely retouched bladelets (Fig. 11); and armed double-grooved spears, analogues of the Afontova Gora type. The absence of radiocarbon dates poses several problems for the dating of this site: the fauna includes mammoth, rhinoceros, reindeer, grouse, and bison (Gromov, 1948); the stratigraphic position is associated with the base of the alluvia of the second terrace of the river Tchusovaya, which might suggest either the period of the Oula-Lascaux interval or the beginning of the Tardiglacial.

Traces of industries of the same type are found in the far north of the Russian Plain on the river Petchora, not far from the Arctic Circle (see Fig. 8). There are two sites, notably the Medveja cave (Guslitser and Kanivets, 1965) and the upper

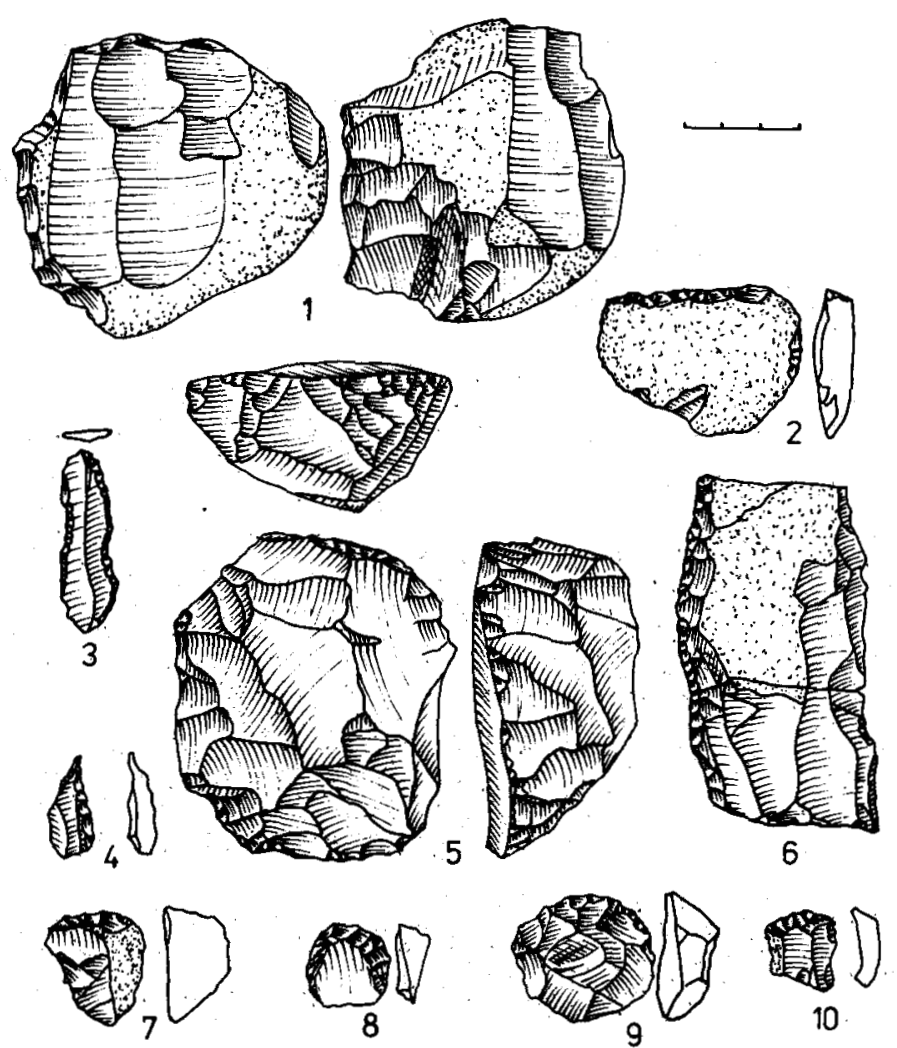

FIG. 11. Talitski site on River Tchusovaya $\left(58^{\circ} \mathrm{N}\right)$. Stone tool industry: 1 - blade core; 2,6 - sidescrapers; 3,4 - perforators; 5 - thick endscraper; 7-10 - short scrapers. (Collection of the Museum of Anthropology of the University of Moscow.) 
level of the open-air site of Krutaya Gora (Kanivets, 1976). Although the inventories are limited, the same types of core and retouched tools are observed as at the Talitski site (e.g. scrapers and finely retouched bladelets; Fig. 12). The dating of these two sites is also problematical: pollen analysis of the sediments of the Medveja cave (lower level) indicates the absence of elements typical of the tundra, and the presence of pollens more characteristic of a steppe environment. Among the fauna, reindeer predominates $(>20 \%)$, followed by hare, although there are some steppe elements (Ochotona) among the rodents, and the presence of horse and bison also confirms a steppe environment (Table 3). It was probably the absence of snow during the winter, rather than a very rigorous climate, that attracted large numbers of reindeer, ptarmigan, and other tundra species. Later fauna and flora (from the middle level of the Medveja cave) confirm a steppe-forest environment, leading to the conclusion that these levels date from the Tardiglacial substages (Bölling or Alleröd).
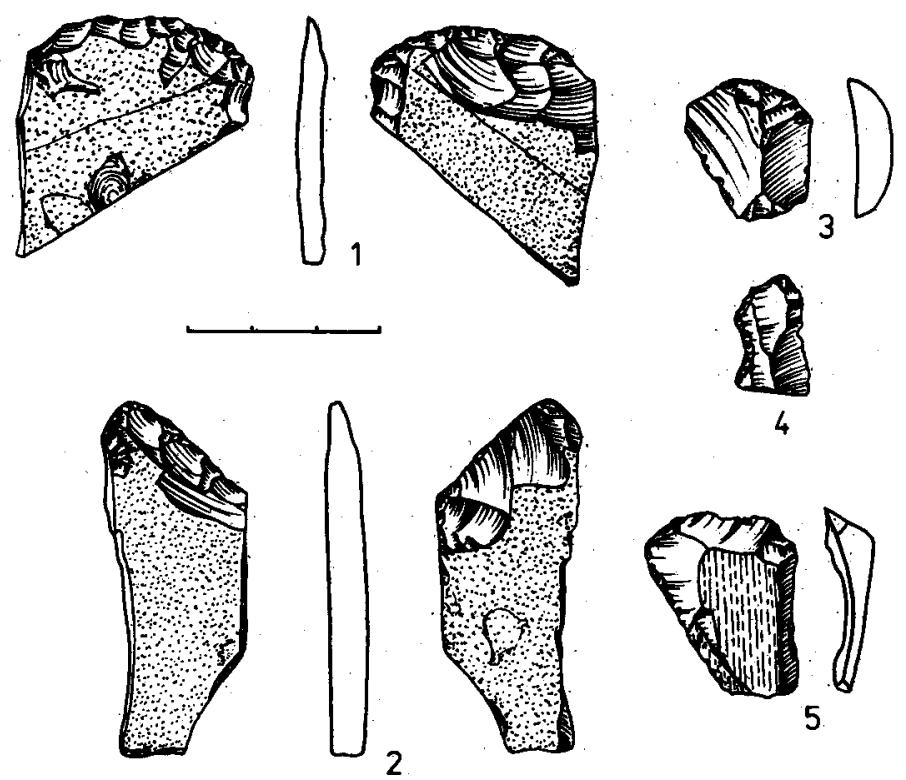

FIG. 12. Medveja cave $\left(63^{\circ} \mathrm{N}\right)$. Stone tool industry of lower level:.1,2 - bifacial sidescrapers on flint tablets; 3 - short endscraper; 4 - finely retouched bladelet; 5 - retouched flakes (Guslitser and Kanivets, 1965).

There is no proof that Tardiglacial colonization of the northern Russian Plain and the Urals lasted until the beginning of the Holocene. A new wave appeared only at the beginning of the Atlantic, in the upper Kama basin, and then advanced northward, reaching the Petchora and Vytchegda basins. This wave is represented by the Kama culture (Bader, 1966; Bourov, 1973)." The other (perhaps earlier) wave advanced from the western Russian Plain across the Dvina basin, and is associated with the Kunda culture which represents the last descendants of the Swidérian. The two waves met in the Petchora basin, where the discoveries of Vis Peat Bog I, dated at $8080 \pm 90 \mathrm{yr}$ and $7090 \pm 70 \mathrm{yr}$ BP, give the most complete picture of an adaptation to taiga conditions, including many elements of the Kunda culture such as tanged points. Objects of wood and bone are also preserved, including bows and ar-
TABLE 3. Faunal remains at Medveja cave (numbers of bones)

\begin{tabular}{|c|c|c|c|}
\hline \multirow[b]{2}{*}{ Species } & \multicolumn{3}{|c|}{ Level } \\
\hline & $\begin{array}{c}\text { Lower } \\
\text { (brown clay) }\end{array}$ & $\begin{array}{c}\text { Middle } \\
\text { (grey clay) }\end{array}$ & $\begin{array}{l}\text { Upper } \\
\text { (scree) }\end{array}$ \\
\hline Mammoth & 73 & 42 & - \\
\hline Rhinoceros & 57 & 20 & 2 \\
\hline Aurochs or Bison & 21 & 18 & 1 \\
\hline Muskox & 109 & 16 & 2 \\
\hline Horse & 217 & 62 & 9 \\
\hline Elk & 11 & 7 & 1 . \\
\hline Saiga antelope & 20 & 5 & 2 \\
\hline Roe deer & 17 & 4 & - \\
\hline Reindeer & 2271 & 1282 & 83 \\
\hline Cave bear & 414 & 362 & 39 \\
\hline Brown bear & - & 5 & 1 \\
\hline Cave lion & 4 & 5 & 1 \\
\hline Wolf & 144 & 74 & 8 \\
\hline Red fox & 595 & 101 & 10 \\
\hline Arctic fox & - & 3 & - \\
\hline Mustelids & 7 & - & - \\
\hline Weasel & 10 & 1 & - \\
\hline Ermine & 8 & - & - \\
\hline Wolverine & 13 & 1 & - \\
\hline Marten & 6 & - & - \\
\hline Hare & 2304 & 198 & 12 \\
\hline Grouse & 3102 & 117 & 3 \\
\hline
\end{tabular}

rows of wood, elements of skis and sledges, bark receptacles, and nets (Fig. 13).

The origin of the Kama culture is linked to the influence of Siberian industries arriving in Europe across the southern. Urals (Fig. 14). This is confirmed by the presence not only of Siberian elements (finely retouched bladelets of the Borki type and Siberian-type tanged points) but also of southern elements (e.g. trapezis and flat harpoons) probably transmitted by the Yangelka culture (Matiouchine, 1969). Further confirmation is provided by the fact that the same route across the southern Urals had already been used during the Tardiglacial phase, given that in the upper level of Krutaya Gora on the Petchora, Kanivets (1976:75) found two obsidian tools, doubtless of southern origin.

\section{THE PALEOHISTORY OF. NORTHERN AND. NORTHEASTERN SIBERIA}

The Asiatic Lower and Middle Paleolithic industries are associated with hot (dry or wet) climates: their distribution is limited to southern regions which extend no further than $45^{\circ} \mathrm{N}$. The Siberian finds attributed by Okladnikov to the Lower Paleolithic (Oulalinka, Filimoshki, Kumara I) must be treated prudently in view of the nature of the artifacts (pebble tools) and their stratigraphic position (Okladnikov and Vasilevskiy, 1980; Powers, 1973). Siberian colonization appears to have begun only in the Kargino period (Würm Interpleniglacial). The hypothesis that $50^{\circ} \mathrm{N}$ latitude was crossed in Siberia only during the Upper Paleolithic is based on solid evidence (Okladnikov and Abramova, 1974:185). Some authors hold that this northerly migration was precipitated by the increasing aridity of the climate of the Asiatic desert zone during the Zyrianka glaciation (Early Würm). The occupation of Siberia, which during the Kargino Interpleniglacial phase was colder and less wooded than now, influenced the adapta- 

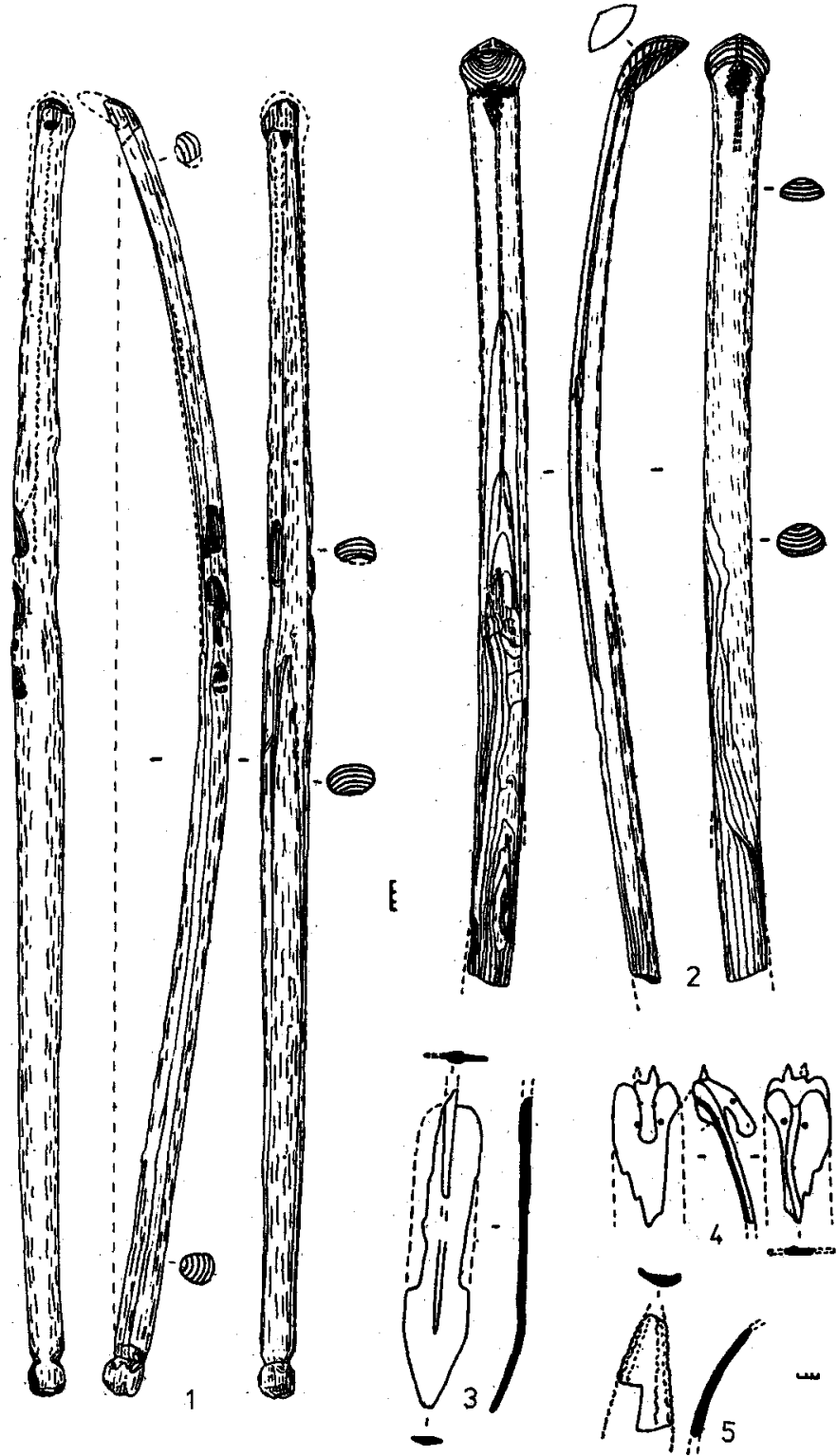

FIG. 13. Vis Peat Bog I. Wooden objects: 1,2 - bows; 3 - oar; 4,5 - ski fragments (Bourov, 1980).

tion of Upper Paleolithic groups to these conditions. This process may be seen within the framework of several different cultural traditions which were established in eastern Siberia on the basis of various cultural streams coming from the south.

1) Lithic industries with a flake technology, derived from the Levallois-Mousterian of Central Asia, appeared south and east of Baikal (for example, Tolbaga dated between $34860 \pm$ 2100 and $27210 \pm 300 \mathrm{BP}$; Konstantinov, 1980; and Varvarina Gora dated to $30600 \pm 500 \mathrm{BP}$; Okladnikov and Vasilevskiy, 1980). Besides the mammoth and rhinoceros, the fauna is characterized by species of a steppe environment (the horse [Equus hemionus and Equus caballus], bison, saiga antelope, and gazelle).

2) Industries producing choppers, bladelets, and flakes, principally obtained from a keel-shaped Gobi core, originated in eastern Asia (China, Ordos, Mongolia), and are fairly wide-

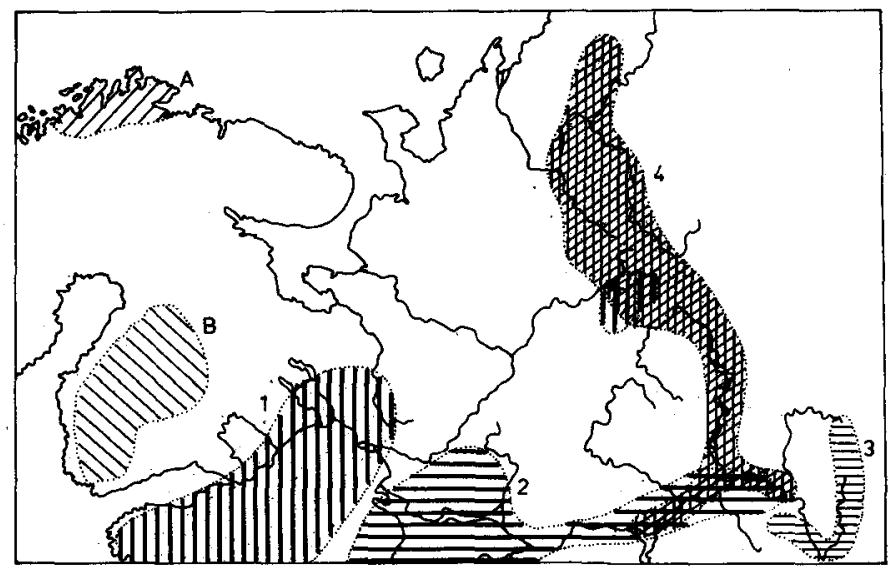

FIG. 14. Early Holocene cultures. in northeastern Europe: 1 - Kunda; 2 - Upper Volga; 3 - Yangelka; 4 - Kama; A - Komsa; B - Suomusjärvi (Kozlowski, 1975).

spread in eastern Siberia. Their date is controversial: Mochanov (1977) suggests that certain sites on the Aldan (Ejantsy Ikhine) date from the first half of the Kargino Interpleniglacial (35 $400 \pm 600$ and $35600 \pm 900$ BP for the base of the third terrace of the Aldan at Oust' Mil II); Abramova (1980) has reservations with respect to dates before $20000 \mathrm{BP}$ for sites in the Aldan basin.

The faunal remains from the Ikhine II site indicate a steppe rather than a tundra environment (preponderance of horse and bison over mammoth and reindeer), which seems to be more consistent with the Interpleniglacial age. In the same technological grouping there are sites which may be dated without any doubt to the beginning of the Sartan glaciation (Late Würm), belonging to the Afontova Gora culture, distributed along the banks of the Yenisey south of Krasnoyarsk (Afontova Gora II $-20900 \pm 300$ BP; Tachtik I $-12180 \pm 120$ BP). These mammoth-hunters already had semi-subterranean pit huts.

3) The Malta-Buret' culture is characterized by an entirely different blade technology (without Gobi cores), and tools comprising chiefly retouched blades, burins, perforators, and scrapers. The origin of this culture is not yet known; but it has no direct connection with the European Upper Paleolithic, as has been suggested by several authors who attribute to it an Aurignacian or Gravettian character (e.g. Müller-Beck, 1966, 1979). More probable are relatively direct links with central Asia, where the Samarkand culture bears some analogies with Malta, though the correlation between the two. sites does not exceed a coefficient of taxonomic distance of 0.37 (see Djourakoulov et al., 1980:94).

The chronological position of the Malta-Buret' culture, established by geological stratigraphy, is at the end of the Kargino Interpleniglacial phase or the beginning of the Sartan glaciation. This culture has certain features similar to European Gravettian (e.g., artistic manifestations, clothing reconstructed from statuettes, female ivory statuettes) which should be classified according to the system of adaptation to periglacial conditions, particularly steppe-tundra, rather than phyletically. The mammoth-hunters of Malta-Buret' were well 
equipped to survive in the Angara valley during the Sartan glaciation.

The first human groups to appear in Siberia during the end of this period (Kargino-Early Sartan) represented typically Asiatic cultural traditions associated with the regions south of Siberia. Both this fact and the paleogeography of western Siberia oppose the hypothesis of an east European origin for the peopling of Siberia in the Upper Paleolithic. On the contrary, central Asia must have played a major role in this process.

The first human groups entered America towards the end of the Kargino Interpleniglacial phase, coming from Siberia by way of Beringia (Lorenzo, 1978; Kozlowski and Bandi, 1981). It must therefore be accepted that one of the east Siberian cultural complexes mentioned above began this penetration. Technological and typological analysis of the first tool industries in North America shows that it was probably a chopper and blade complex, which, in fact, occupied the most northerly position among Asiatic Upper Paleolithic industries (Aldan Valley sites). Since this technology is more representative of an adaptation to cold steppe conditions rather than those of the tundra, and no sites of this period are known in northeastern Siberia, it would seem that the first penetration across Beringia was rather ephemeral and relatively swift. The migrating groups took advantage of the continental corridor and moved rapidly southwards, finding familiar steppe conditions south of the Wisconsian periglacial zone.

The first people who spread through Beringia were thus not the ancestors of the peoples of the American and Asiatic arctic zones. The process of periglacial adaptation initially had to be completed in Siberia during the first half of the Sartan glaciation, laying the foundation for a real conquest of the far northeast of Asia during the Eri (Lascaux) interstadial between 17000 and $14500 \mathrm{BP}$.

Leaf-shaped point industries appeared in both Asia and America during this period. These industries could not have arisen locally, contrary to Lartichev's $(1976,1977)$ sugges- tion, as the presence of Acheulian-type industries has not been definitively confirmed in eastern Asia. Furthermore, no transitional forms are found in Asia between Acheulian bifacial blades and the invading flat retouched leaf-shaped points. It is necessary to consider other hypotheses which admit the western origin of Asiatic leaf-shaped points and which account for the fact that these points appear in a Levallois-Mousterian context in southeastern Europe, in the Caucasus, and also in Soviet Central Asia (e.g. the Khazakhstan sites near Lake Abkhash). The fact that the Levallois-Mousterian influence extended to Mongolia and southern Siberia suggests that the first leaf-shaped points appeared in east Asia in this context. In any event, these points have no connection with the leaf point industries of the European Plains, as suggested by MüllerBeck $(1966,1979)$. Asiatic leaf point cultures therefore do not represent an adaptation to periglacial conditions; their central Asian origin is more indicative of an adaptation to a cold steppe environment. It was only in eastern Siberia, during the Sartan main phase, that the adaptation of these groups to tundra conditions began, allowing leaf point industries to advance northwards between 17000 and $13000 \mathrm{BP}$ as far as the Aldan Basin and Chukotka. The leaf point industries represented in levels IX-VIIA of the cave at Diouktay on the Aldan are characterized by a blade technique and by tools such as burins, scrapers, finely retouched bladelets, and pressure-chipped retouched elongated leaf points to which were sometimes added a steeply retouched edge (Mochanov, 1977). The fauna of levels IX-VIII of the Diouktay cave is dominated by mammoth, followed by arctic hare, grouse , and lemming; reindeer, horse, and bison are also present. Later (level VIIA) the reindeer became dominant (Table 4).

This adaptation of the Diouktay industries to tundra conditions facilitated penetration into the Siberian far north; for example, there is the Berelekh site $\left(71^{\circ} \mathrm{N}\right)$, dated at $12930 \pm 80$ and $13420 \pm 200 \mathrm{BP}$ and thus more recent than the eponymous Diouktay site. The tools at Berelekh include slender laurel-leaf points, retouched blades, splintered pieces (Fig.

TABLE 4. Faunal remains at Diouktay sites (numbers of bones)

\begin{tabular}{|c|c|c|c|c|c|c|c|c|c|c|c|c|}
\hline \multirow[b]{2}{*}{ Species } & \multicolumn{5}{|c|}{ Diouktay } & \multicolumn{3}{|c|}{ Ust-Mil } & \multicolumn{3}{|c|}{ Ikhine I } & \multirow[t]{2}{*}{ Berelekh } \\
\hline & IX & VIII & VIIB & VIIb & VIIA & $\mathbf{A}$ & B & C & I & II & III & \\
\hline Rhinoceros & - & - & - & - & - & - & 3 & 1 & - & 1 & - & 7 \\
\hline Mammoth & 132 & 621 & 7 & 4 & 24 & 4 & 7 & 2 & 1 & 3 & 1 & 78 \\
\hline Bison & 6 & 3 & 3 & 1 & 2 & 3 & - & 5 & 3 & 3 & 3 & $3(?)$ \\
\hline Horse & 2 & - & 9 & 4 & 1 & 9 & - & 7 & 1 & 4 & 2 & - \\
\hline Muskox & - & 1 & - & - & - & - & - & - & - & - & - & - \\
\hline Reindeer & 4 & 3 & 2 & 1 & 32 & 3 & - & - & 2 & 5 & - & 1 \\
\hline Elk & - & 5 & - & 3 & 33 & - & - & - & - & - & 1 & - \\
\hline Deer & - & - & - & - & - & - & - & - & - & - & - & - \\
\hline Lion & - & 6 & - & 3 & - & - & - & - & - & - & - & - \\
\hline Wolf & - & 4 & - & - & 4 & - & - & - & - & - & - & - \\
\hline Fox & 2 & 3 & - & 3 & 9 & - & - & - & - & - & - & - \\
\hline Arctic fox & 6 & 16 & 1 & 12 & 12 & - & - & - & - & - & - & - \\
\hline Hare & 66 & 61 & 20 & 21 & 38 & - & - & - & - & - & - & 828 \\
\hline Lemming (1) & - & 1 & 17 & - & - & - & - & - & - & - & - & - \\
\hline Lemming (2) & 1 & 3 & 7 & - & - & - & - & - & - & - & - & - \\
\hline Rodents & 21 & 38 & 191 & 32 & 39 & - & - & - & - & - & - & - \\
\hline Birds & 22 & 24 & 4 & - & 2 & - & - & - & - & - & - & 92 \\
\hline Fish & 3 & 7 & - & - & 2 & - & - & - & - & - & - & 2 \\
\hline Not determined & 1081 & 2938 & 2309 & 545 & 1419 & 7 & 4 & 8 & 1 & 9 & 3 & 10 \\
\hline
\end{tabular}


15). The Gobi core technique is still present. The fauna is completely dominated by the mammoth $(98.6 \%)$, accompanied by rhinoceros, bison, horse, reindeer, lion, wolf, and wolverine. An image of a mammoth engraved on a mammoth tusk is attributed to this site (Fig. 16; Bader, 1972). The Mayorych site $\left(63^{\circ} \mathrm{N}\right)$ probably belongs to the same tradition although the tools are poor (Mochanov, 1977).
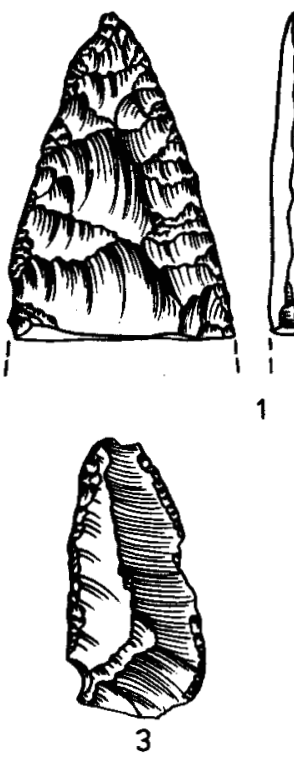

1

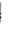

\section{(1)}
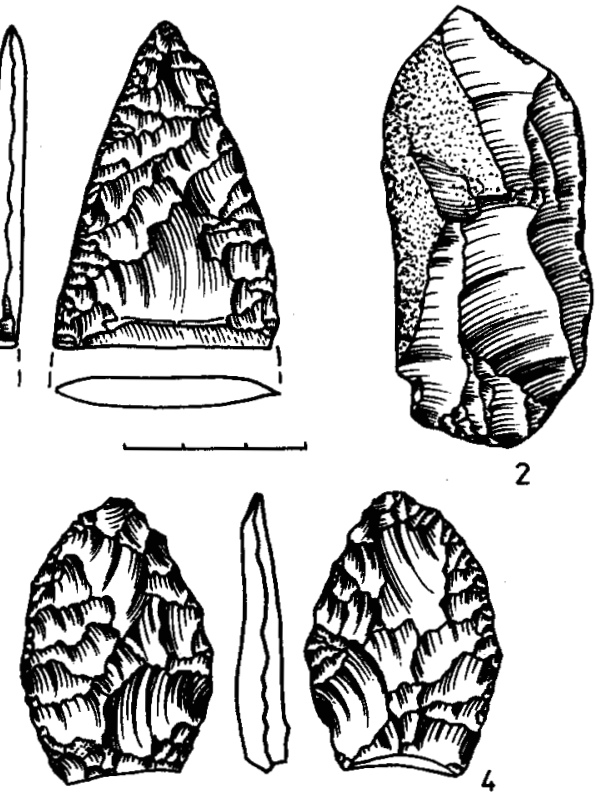

2
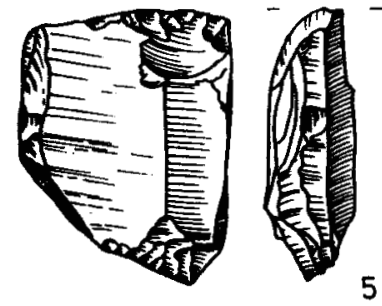

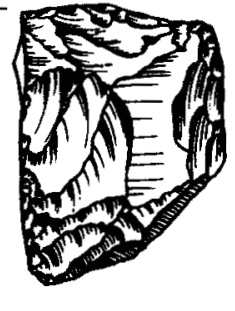

FIG. 15. Berelekh (Indigirka basin) at $71^{\circ} \mathrm{N}$. Stone tool industry of the Diouktay culture: 1,4 - leaf points; 2,3 - retouched blades; 5 - splintered piece (Mochanov, 1977).

There are thus several indications that the Diouktay culture represents an adaptation of mammoth hunters to extreme periglacial conditions, facilitating both the penetration and systematic exploitation of the northeastern Asian Arctic by these groups.

Other leaf point industries existed in northeastern Siberia during the Sartan galciation (especially towards the end of this period), e.g., the Ouchki industry of Kamchatka (Dikov, 1979) which has the oldest tanged bifacial points, and that of Khoukhtoui III on the littoral of the Sea of Okhotsk (Mochanov, 1977), where the leaf points are characterized by certain unifacial points and by the absence of Gobi-type cores. One of these units, or perhaps their common ancestor, certainly played an important part in the introduction into North America of the first leaf point industries which formed the PreLlano horizon.

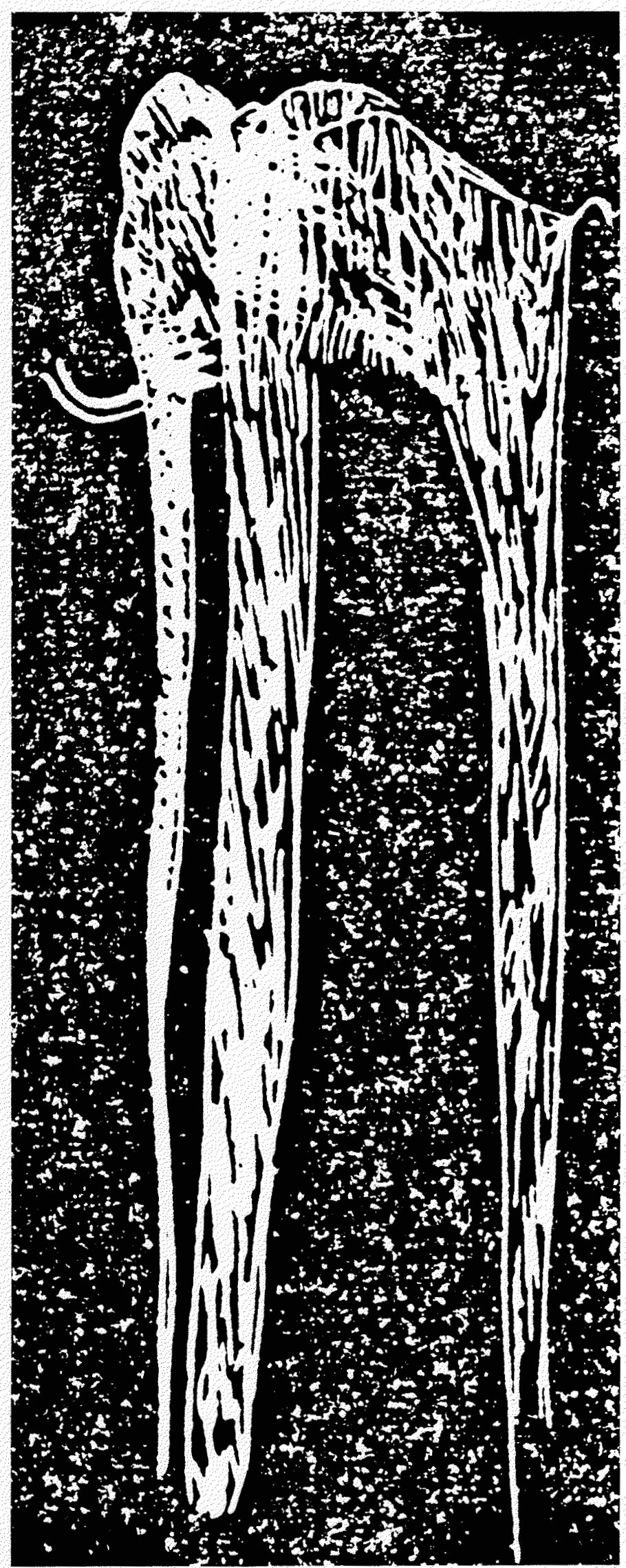

FIG. 16. Berelekh (Indigirka basin) at $71^{\circ} \mathrm{N}$ : representation of mammoth on mammoth tusk (Bader, 1972). 
The first wave of human groups adapted to the conditions of the Asiatic far north disappeared with the extinction of the large Pleistocene fauna, in particular the mammoth. The industries that persisted until the end of the Pleistocene and into the Holocene were part of a blade and chopper technological complex. They are known mainly in the Kolyma basin, e.g. at the Kongo site (lower level: $9740 \pm 530 \mathrm{BP}$, upper level 8655 $\pm 220 \mathrm{BP}$ ) and at the Siberdik site (upper level: $8480 \pm 200$ and $8020 \pm 80 \mathrm{BP}$; Dikov, 1979). The tools at these sites, apart from choppers, include conical blade cores, end scrapers, burins, finely retouched bladelets, side scrapers, and a few leaf points including unifaces, reminiscent of specimens from the Japanese islands (Fig. 17). Although the faunal remains suggest reindeer- and horse-hunting, it is probable that these groups represent a Pacific coastal tradition.
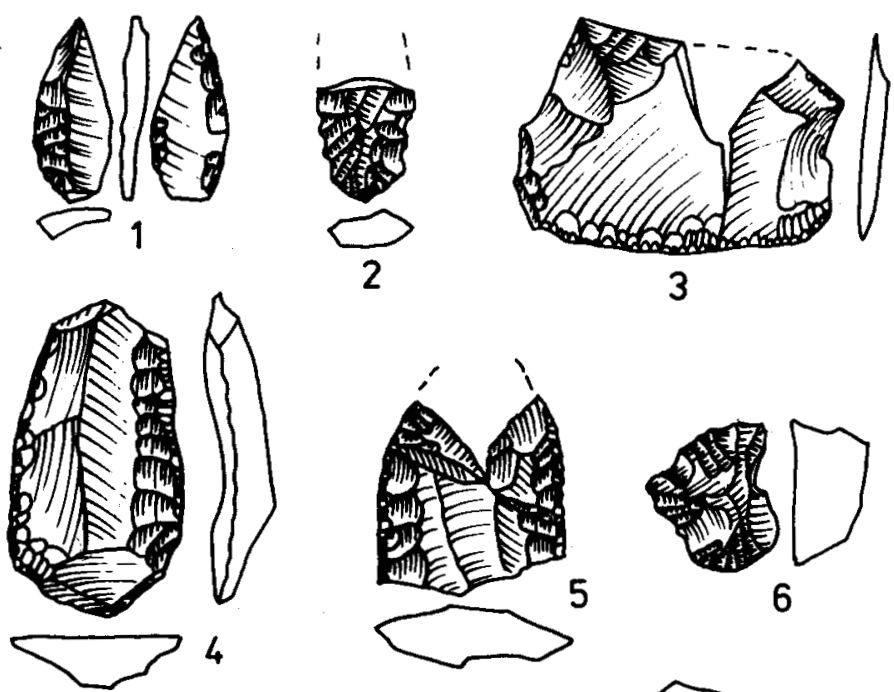

3
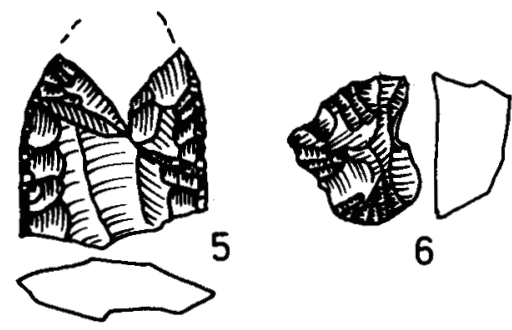

6

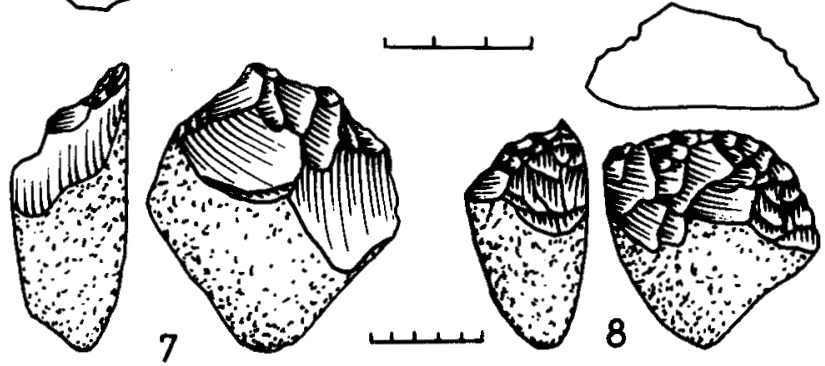

FIG. 17. Kongo, in the Kolyma basin $\left(63^{\circ} \mathrm{N}\right)$. Stone tool industry: 1 - partially bifacial point; 2 - fragment of unifacial point; $3,4,5$ - sidescrapers, 6 - endscraper; 7,8 - pebble tools (Dikov, 1979).

On the other hand, the Soumnagin culture represents a tradition typical of almost all of Siberia at the beginning of the Holocene. It was recognized in the Aldan basin by Mochanov $(1969,1977)$. The Soumnagin culture is characterized by a special blade technique that produced very fine, long, narrow bladelets from prepared single platform cores. After breaking, these blanks were transformed into burins, endscrapers, retouched truncations, and perforators. Some rare splintered pieces and bifacial chipped axes were also found. The appearance of bladelets (Fig. 18) with fine alternate retouching, recalling the Borki bladelets, and of tanged points with a flat re- touch at the base, allows this culture to be included in a wider complex, spread across the whole of Siberia as far as eastern Europe. This complex is denoted by Müller-Beck (1979) as "Industrien mit schmalbahnigen Klingenkernen".
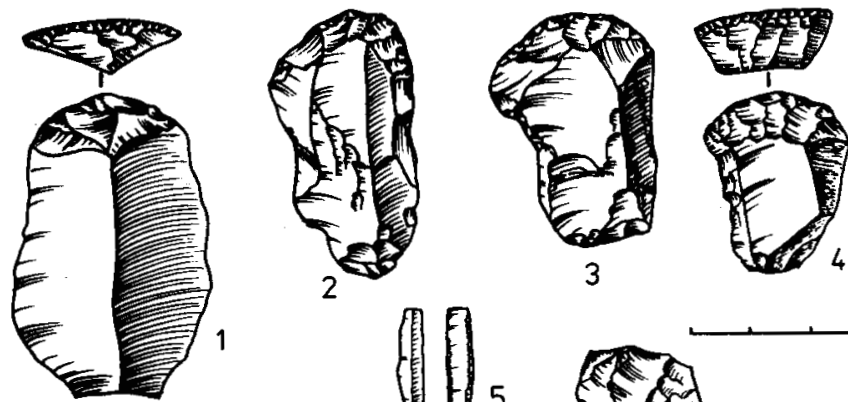

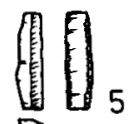
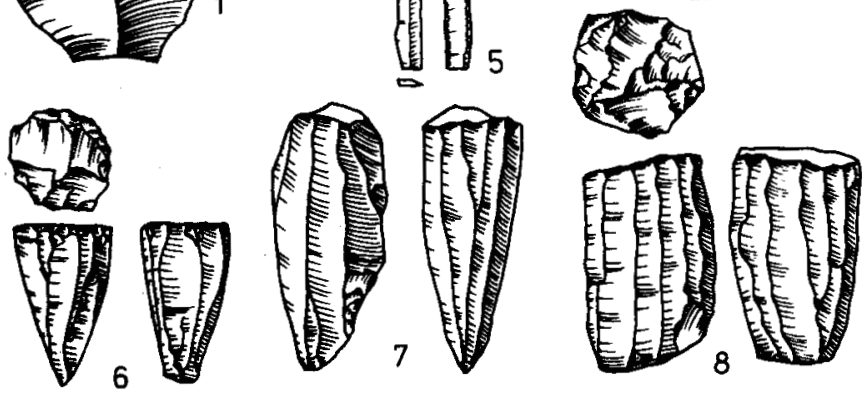

FIG. 18. Panteleykha sites (I-VIII) on the lower Kolyma $\left(69^{\circ} \mathrm{N}\right)$. Stone tool industry of the Sumnagin culture: 1-4 - endscrapers on blades; 5 - finely retouched bladelet; 6-8 - blade cores (Mochanov, 1977).

The Soumnagin culture at Belkachi is dated after $8700 \mathrm{BP}$, at Ust-Timpton between 10650 and $6380 \mathrm{BP}$, and at Soumnagin after $6280 \mathrm{BP}$. This corresponds to a period of the Holocene when taiga forests covered the Kolyma and Indigirka basins, with a northern border some 150 to $200 \mathrm{~km}$ further north than the contemporary edge of the taiga, as indicated by pollen diagrams. The Soumnagin culture therefore represents an adaptation to the Holocene taiga, which is confirmed by the essentially forest fauna of the Aldan basin sites (Table 5). Nevertheless, at about $6000 \mathrm{BP}$, during the climatic optimum, certain groups of the Soumnagin culture advanced even further north, not only to the lower Kolyma (Panteleykha I-VIII; Mochanov, 1977:203-206), but also to the Taimyr peninsula (Tagenar VI and Piasina I; Khlobistine, 1973). Whereas hunting in the Aldan basin was oriented chiefly towards the elk (Mochanov, 1969), in the far north of Siberia it was towards reindeer, bear, deer, and birds. Fish remains are very rare at all of the Soumnagin sites, distinguishing it from the usual reconstruction of the economy of peoples of the early Holocene. The Soumnagin culture thus represents the second wave of peoples to colonize the far north of Asia. It doubtless played an important role in the evolution of the recent arctic peoples of Asia, who were also modified by later migrations from the south of Siberia and probably by contacts with the arctic zone of America.

\section{THE ORIGIN OF THE PEOPLING OF THE ARCTIC ZONE} OF AMERICA

The first penetration of human groups into America left no 
TABLE 5. Fauna of the Belkatchi site sequence (Soumnagin culture)

\begin{tabular}{|c|c|c|c|c|c|c|c|c|c|c|c|}
\hline Species & XXIII & $\mathbf{X X}$ & $\mathbf{X I X}$ & XVIII & XVII & $\mathrm{XVI}$ & XV & XIV & XIII & XII & $\mathbf{X I}$ \\
\hline Elk & $1 a / 1^{b}$ & - & $2 / 1$ & $19 / 3$ & $24 / 7$ & $5 / 1$ & $5 / 2$ & $65 / 9$ & $39 / 5$ & $75 / 8$ & $220 / 19$ \\
\hline Reindeer & - & - & - & - & - & - & - & - & - & $1 / 1$ & $7 / 1$ \\
\hline Siberian deer & - & - & - & - & - & - & - & $7 / 4$ & - & $1 / 1$ & - \\
\hline Roe deer & $1 / 1$ & $5 / 1$ & $5 / 2$ & $1 / 1$ & - & - & $1 / 1$ & $3 / 1$ & - & $1 / 1$ & $18 / 2$ \\
\hline Brown bear & - & - & - & - & - & - & - & - & - & - & $2 / 1$ \\
\hline Rabbit & - & - & $8 / 1$ & - & - & - & - & - & - & - & - \\
\hline Voles and lemmings & - & $23 / 3$ & $22 / 1$ & - & $7 / 1$ & - & - & - & - & - & - \\
\hline Black grouse & - & - & - & - & - & - & - & - & - & - & - \\
\hline Other birds & - & $1 / 1$ & - & - & - & - & - & - & - & $3 / 2$ & $20 / 5$ \\
\hline Fish & - & $9 / 2$ & - & - & $1 / 1$ & - & - & - & - & - & $3 / 2$ \\
\hline
\end{tabular}

aNumber of bones.

bNumber of individuals.

lasting trace in the arctic zone of the New World, because these groups moved further south as quickly as possible to find a steppe environment. The leaf point cultures, ancestors of American Paleo-Indian groups, were much better equipped to survive in arctic conditions. It is to these industries, in particular to the Diouktay culture, that the origin of the peopling of the American arctic zone must be attributed. According to a new hypothesis (Hadleigh-West, 1981), the predecessors of the Diouktay culture and those of the American paleo-arctic tradition (Anderson, 1970) must be sought in Beringia. This would mean that this population arrived in Beringia before the introduction of specialized bifacial points, and spread into both Siberia and Alaska after their invention. This seems unlikely in the context of Asian data which indicate gradual progress in colonization from southwest to northeast, paralleling adaptation to the periglacial conditions of the Sartan glaciation.

Alaskan industries (e.g. Akmak and Denali) must be placed in the framework of the American Paleo-arctic tradition identified by Anderson (1970) and Dixon (1970), and dated between 13000 and $8000 \mathrm{BP}$, or during the recent Woodfordian and the Valders substage. Akmak, known from the base level of the Onion Portage site on the middle reaches of the Kobuk in northwest Alaska, is characterized by the presence of two elements, microlithic and macrolithic. The macrolithic element comprises bifacial tools with flat progressive retouching, and blade tools; the microlithic element is represented by very small bladelets obtained from Gobi cores (Andersson, 1970). The Denali industry, recognized for the first time at the famous "Campus site" near Fairbanks, also includes Gobitype cores for the manufacture of microlithic blades, blade burins, bifacial leaf points, and flake scrapers (HadleighWest, 1967). A relationship between these industries and the Diouktay culture seems probable, and is, moreover, confirmed by the successful economic adaptation of groups of this culture to arctic conditions. These leaf point complexes mark not only the first peopling of the arctic zone of Asia, but also the continuation of the migration towards America.

Towards the end of this period, between 10000 and 8000 BP, industries without leaf-shaped artifacts appeared in Alaska, known from the Gallagher Flint Station (Dixon, 1975) and the islet of Anangula (Laughlin and Marsh, 1954; Laughlin and Aigner, 1966). The former site is characterized by cores of different forms, in general intended for the production of fairly large blades; however, there are also Gobi cores used for the manufacture of microliths. The second site apparently lacks Gobi cores. The technical character and typological composition suggest a connection with the Soumnagin culture, although this hypothesis remains to be confirmed by a more detailed study of Alaskan industries.

Current research indicates that development from a leaf point technocomplex (Akmak, Denali) led first to industries of the Denbigh type or Arctic Small Tool tradition (Giddings, 1964; Irving, 1970) and later to the true Eskimo culture. In contrast, the technocomplex without leaf-shaped points (Gallagher Flint Station, Anangula) probably had no discern-

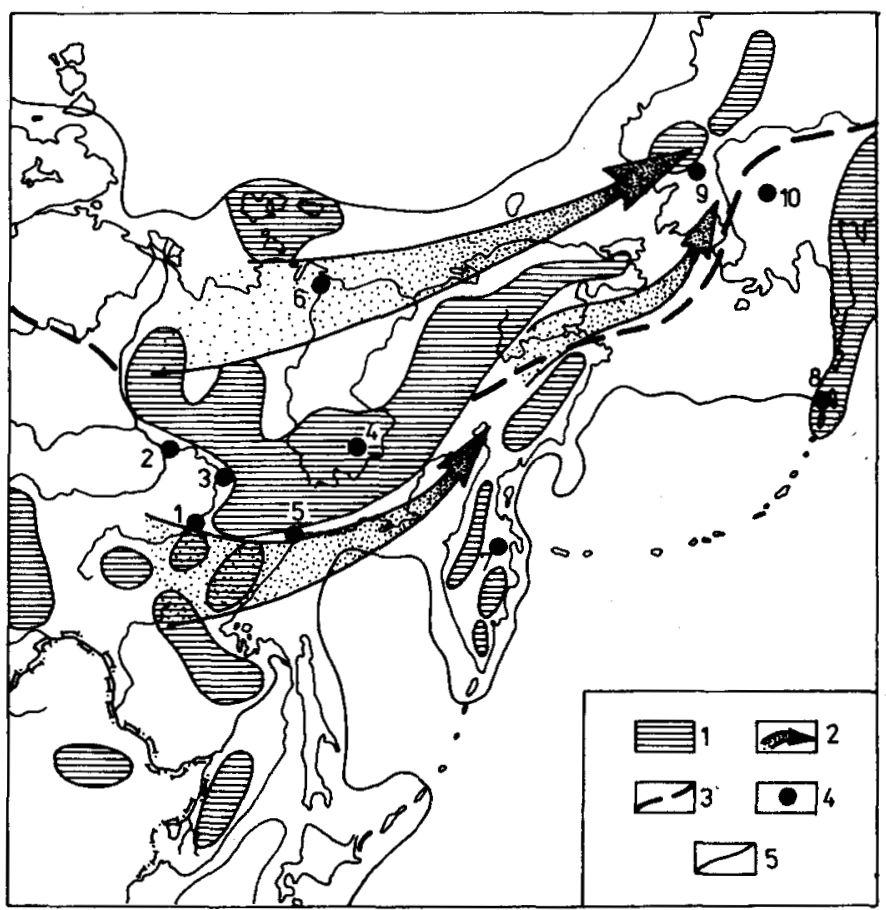

FIG. 19. The archaeological and paleogeographical situation during the Pleniglacial and Tardiglacial phases in northeastern Asia and northwestern America (Key): 1 - Sartan and Wisconsin glaciers; 2 - migrations from Asia into America during the Sartan glaciation and the Tardiglacial phase; 3 -northern limit of the taiga; 4 - archaeological sites; 5 - limit of marine retreat. Main archaeological sites (numbers on map): 1 - Diouktay; 2 - Ikhine; 3 - Ejantsy; 4 - Mayorytch; 5 - Kukhtui III; 6 - Berelekh; 7 - Uchki; 8 - Anangula; 9 - Akmak; 10 - Onion Portage. 
TABLE 6. Paleogeographical conditions and northward cultural migrations during the last glaciation and the early Holocene

\begin{tabular}{|c|c|c|c|c|c|}
\hline & Europe & & Asia & & America \\
\hline \multirow{2}{*}{ 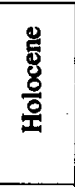 } & \multirow{2}{*}{$\begin{array}{l}\text { Siberian (Kama culture) occupation of the } \\
\text { arctic zone from the southern Urals. } \\
\text { Retreat of reindeer hunters to European far } \\
\text { north (Komsa and Kunda cultures). }\end{array}$} & \multirow{2}{*}{$\frac{8}{8}$} & \multirow{2}{*}{$\begin{array}{l}\text { Occupation of the arctic zone by new } \\
\text { groups from southern and southeastern } \\
\text { Siberia. Establishment of Soumnagin } \\
\text { culture in north Siberia and Asiatic littoral } \\
\text { cultures (Kongo, Siberdik) in northeast. }\end{array}$} & \multirow{2}{*}{ 总 } & $\begin{array}{l}\text { Continuation of American Paleo-arctic } \\
\text { tradition (Denbigh). }\end{array}$ \\
\hline & & & & & \multirow{2}{*}{$\begin{array}{l}\text { Formation of American Paleo-arctic } \\
\text { tradition (Akmak, Denali). } \\
\text { Occupation of arctic zone by blade and } \\
\text { leaf point cultures. Retreat of Paleo-Indian } \\
\text { groups to the North. }\end{array}$} \\
\hline 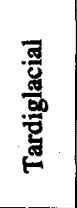 & $\begin{array}{l}\text { Repopulation of the Plain. Adaptation to } \\
\text { arctic conditions following retreat of last } \\
\text { glaciation (tanged point complex). First } \\
\text { Siberian penetrations into northeast } \\
\text { (Talitski, Medveja Cave, upper level of } \\
\text { Krutaya Gora). }\end{array}$ & 鄫 & $\begin{array}{l}\text { Extension of occupation of northern zone } \\
\text { (leaf point technocomplex, primarily } \\
\text { Diouktay culture). Continuation of local } \\
\text { traditions. }\end{array}$ & $\frac{\text { क्षे }}{7}$ & \\
\hline 容产 & $\begin{array}{l}\text { Advance of the ice sheet to northern Plain } \\
\text { rendering it inaccessible to occupation. }\end{array}$ & 䔍 & $\begin{array}{l}\text { Occupation of northeastern Siberia and the } \\
\text { Pacific littoral by different cultural } \\
\text { traditions, particularly leaf-shaped point } \\
\text { industry. }\end{array}$ & 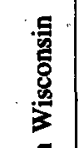 & $\begin{array}{l}\text { Second penetration: groups adapted to } \\
\text { periglacial conditions (leaf point traditions, } \\
\text { predecessors of Paleo-Indians). }\end{array}$ \\
\hline \multirow[b]{2}{*}{ 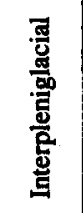 } & \multirow{2}{*}{$\begin{array}{l}\text { Occupation of the Plain and incursions into } \\
\text { the arctic zone (Soungirian or Kostienki- } \\
\text { Soungir culture). }\end{array}$} & \multirow[b]{2}{*}{ 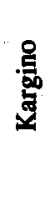 } & \multirow{2}{*}{$\begin{array}{l}\text { Northern advance of different groups and } \\
\text { occupation of eastern Siberia north of } 50^{\circ} \\
N \text {. Probably the result of increasing aridity } \\
\text { in central Asia. }\end{array}$} & $\sum^{\pi}$ & \\
\hline & & & & 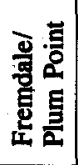 & $\begin{array}{l}\text { First penetration: groups not adapted to } \\
\text { arctic conditions (chopper and blade } \\
\text { technocomplex). } \\
\text { Not occupied. }\end{array}$ \\
\hline 蛋㤐 & $\begin{array}{l}\text { Northern zone inaccessible because of ice } \\
\text { sheet advance. First adaptations to arctic } \\
\text { conditions in periglacial. }\end{array}$ & 嘼 & $\begin{array}{l}\text { Not occupied north of } 45^{\circ} \mathrm{N} \text {; colonization } \\
\text { limited to central regions. }\end{array}$ & 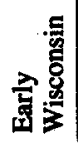 & Not occupied. \\
\hline
\end{tabular}

ible material continuation. It is also possible that the northward movement of Paleo-Indian cultures, following the retreat of the Valders substage, played a role in the formation of the Paleoeskimo culture.

\section{CONCLUSIONS}

We have attempted to show that the circumpolar arctic zone was colonized from different regions of Eurasia. This penetration took place at different stages according to the evolution of paleogeographical conditions during the last glacial phase and the early part of the Holocene (Table 6, Fig. 19).

\section{REFERENCES}

ABRAMOVA, Z.N. 1980. On the dating of the Paleolithic of Aldan. Sovietskaya Arkheologuia. Vol. 4.

ANDERSON, D.D. 1970. Akmak. An Early Archaeological Assemblage from Onion Portage. Acta Arctica. Vol. XV1.

BADER, O.N. 1955. Early Paleolithic of Ural and Povolzhe. Outcheniye Zapiski Permskogo Universiteta. Vol. VII. Fasc. 2.

1960. Etapes principales de l'ethnohistoire et de paléogéographie de l'Oural. Materiali i issledovaniya po arkheologui SSSR. Vol. 79.

1966. Mésolithique de la région de l'Oural et quelques problèmes généraux de l'étude du Mésolithique. Materiali i issledovaniya po arkheologui SSSR. Vol. 126.

1971. Le plus ancien peuplement du Nord de l'Europe a la lumiere des données récentes. Kratkiye soobchtcheniya Instituta Arkheologui. Vol. 126

1972. L'artiste a dessiné de la nature.... Priroda. 9:95-96.

1978. Le site. Paléolithique de Soungir. Moscou.
BANDI, H.G. 1967. Eskimo Prehistory. The University of Alaska Press. and KOZLOWSKI, J.K. 1981. Les racines asiatiques du premier peuplement de l'Amerique. Societé Suisse des Americanistes.

BOE, J., and NUMMEDAL, A. 1936. Le Finnmarkien. Oslo.

BRONSTEDT, J. 1957. Danmarks Oldtid. Kobenhaven. Vol. I.

BUROV, G.M. 1973. Die mesolithischen Kulturen in aussersten europaisch Nord-Osten. The Mesolithic in Europe. Warsaw.

CAMPBELL, J. 1977. The Upper Palaeolithic of Britain. Oxford. 1980. Les problèmes des subdivisions du Paléolithique supérieur britannique dans son cadre europeen. Bull. de la Soc. Royale Belge d'Anthropologie et de Préhistoire. Vol. 92.

CHMIELEWSKI, W. 1961. La civilisation de Jerzmanowice. Wroclaw.

CLARK, J.G.D. 1936. The Mesolithic Settlement of Northern Europe. Cambridge.

COLLINS, D. 1969. Culture Traditions and Environment of Early Man. Current Anthropology. Vol. 6. Fasc. 1.

DEREVIANKO, A.P. 1978. The Problem of the Lower Palaeolithic in the South East of the Soviet Far East. In: Ikawa-Smith, F. (ed.). Early Palaeolithic in South and East Asia. The Hague.

DIKOV, N.N. 1979. Les anciennes cultures du Nord-Est asiatique: Moskva.

DIXON, E.J. 1975. The Gallagher Flint station, an Early Man Site on the Northern Slope; Arctic Alaska, and its Role in Relation to the Bering Land Bridge. Arctic Anthropology. Vol. 12. Fasc. 1.

DJOURAKOULOV, M.D., et al. 1980. Le site de Samarkanda et sa plac dans le Paléolithique supérieur de l'Asie centrale. Paleolit Sredniey i Vostochnoy Azii. Novosibirsk.

FEUSTEL, R. 1961. Jungpalaolithische Wildbeuter in Thüringen. Weimar. GIDDINGS, J.L. 1964. The Archaeology of the Cape Denbingh. Brown University Press.

GOUSLITZER, B.I., and KANIVETS, V.I. 1965. Paleolithic locality on Petchora. Straigrafia i Periodizatsiya Paleolita Vostotchnoy i Centralnoy Evropy. Moscou.

GRITCHUK, V. 1969. La végétation de la Plaine-Russe du temps moustériens: Priroda i razvitiye pervobytnogo obchtchestva. Moscou. 
GROMOV, V.I. 1948. Les bases paléontologiques et archéologiques de la stratigraphie du Paléolithique. Trudy Instituta Geologitcheskikh Nauk. Vol. 64.

HADLEIGH-WEST, F. 1967. The Donnelly Ridge site and the definition of an early cave and blade complex in central Alaska. American Antiquity. 32(3):360-382. sity Press.

1981. The Archaeology of Beringia. New York: Columbia Univer-

HULLE, W. 1978. Die Ilsenhöhle unter der Burg Ranis. Stuttgart.

IRWING, W.N. 1971. Recent Early Man Research in the North. Arctic Anthropology. 8(2).

KANIVETS, V.I. 1976. Le Pal€olithique du Nord de la Plaine Russe: Moscou.

KHLOBISTINE, L.P. 1973. Les ancienne cultures de Taymir. Kratkiye Soobchtchenia Insituta Arkheologui. Vol. 137.

KONSTANTINOV, M.V. 1980. Les étapes culturales et historiques de la plus ancienne histoire de Zabaikale du Sud-ouest. Arkheologitcheski poisk Severnaya Azia. Novosibirsk.

KOZLOWSKI, J:K., and KOZLOWSKI, S.K. 1977. Epoka kamienia na zie-miach polskich. Warszawa.

KOZLOWSKI, S.K. 1975. Cultural differentiation of Europe from 10th to 5th millenia B.C. Warszawa.

LARITCHEV, V.E. 1976. Discovery of Hand-axes in China and the problem. of the local cultures of the Lower Palaeolithic in East Asia. USPP - IX Congrès - Colloque VII: Nice.

1977. La découverte des bifaces dans l'est de l'Asie. Problemy arkheologui Evrazii i Severnoj Ameriki. Moscou.

LAUGHLIN, W.S., and AIGNER, J.S. 1966. Preliminary Analysis of the Anangula Unifacial Core and Blade Industry. Arctic Anthropology. III(2):41-56.

LAUGHIN, W.S., and MARSH, G.H., 1954. The lamellar Flake Manufacturing Site on Anangula Island in the Aleutians. American Antiquity. Vol. 20. Fasc. 1.

LORENZO, J.L. 1978. Early Man Research in the American Hemisphere. In: Bryan, A.L. (ed.). Early Man in America. Edmonton.

LUHO, V. 1967. Die Suomusjarvi-Kultur. SMYA. Vol. 66.

MADEYSKA, T. 1979. The environment of the Middle and Upper Palaeolithic cultures in.Poland. Quaternary Studies in Poland..Vol. 1.

MATIOUCHINE, G.N: 1969. Sur le caractère de la culture matérielle du Mésolithique au sud de l'Oural. Sovietskya Arkheologuia. Fasc. 3.

MOCHANOV, I.A. 1969. Le site de Belkatchi I et la périodisation de l:Age de la Pierre en Yakoutie. Moscou:

1977. Les plus anciennes étapes du peuplement du Nord-Est asiatique. Moscou.

MÜLLER-BECK, H.J. 1966. Paleohunters in America:-origins and diffusion. Science. 152(3276):

1979. Zur Archaeologie der Amerikanischen Arktis. Beitrage zur Allgemeinen un Vergleichenden Archaeologie. Vol. 1:

OKLADNIKOV, A:P., and ABRAMOVA, Z.N. 1974. Le.premier peuplement de la Sibérie et de l'Extrême Orient. Pervobytniy chelovek i prirodnaya sreda. Moscou.

OKLADNIKOV; A.P., and V.ASILEVSKIY, R.S. 1980. Le Nord de l'Asie au debut de l'Histoire. Novosibirsk.

OTTE, M. 1974. Les pointes à retouches plates du Paléolithique supérieur initial en Belgique. ERAUL. Vol. 2. Serie A:

POWERS, W:R. 1973. Paleolithic Man in Northeast Asia: Arctic Anthropology. Vol. 10. Fasc. 2.

'ROLLAND, N. 1981. The interpretation of Middle Palaeolithic Variability. Man. Vol. 16.

SCHILD; R. 1975. Pónny paleolit: In: Hensel, W. (ed.). Prahistoria ziem polskich. Vol. I. Wroclaw.

1978. Chronestratigraphie et environnement du Palélithique final en Pologne. La fin des Temps glaciaires en Europe. Vol. II. Paris.

SOUKATCHEV, V.N. et al. 1966. Le site du Paléolithique supérieur à Soungir. Moscou.

TALITSKI, M.V. 1940. Le site paléolithique d'Ostrov. Kratkiye Soobschtchenia IIMK. Vol. 4.

TAUTE, W. 1968. Die Stielspitzengruppen in Nordlichen Mitteleurop. Köln.

ZAVERNYAIIEV, F.M. 1978. Le site paléolithique de Khotylevo. Moscou. 